DEMOGRAPHIC RESEARCH

VOLUME 40, ARTICLE 39, PAGES 1111-1152 PUBLISHED 30 APRIL 2019

http://www.demographic-research.org/Volumes/Vol40/39/

DOI: 10.4054/DemRes.2019.40.39

Research Article

\title{
Changes in gender role attitudes following couples' residential relocations
}

\section{Sergi Vidal}

\section{Philipp M. Lersch}

This publication is part of the Special Collection on "Spatial Mobility, Family Dynamics and Gender Relations," organized by Guest Editors Sergi Vidal and Johannes Huinink.

(C) 2019 Sergi Vidal \& Philipp M. Lersch.

This open-access work is published under the terms of the Creative Commons Attribution 3.0 Germany (CC BY 3.0 DE), which permits use, reproduction, and distribution in any medium, provided the original author(s) and source are given credit.

See https://creativecommons.org/licenses/by/3.0/de/legalcode. 


\section{Contents}

1 Introduction 1112

2 Background 1113

$2.1 \quad$ Study context 1113

2.2 Previous literature 1115

2.3 Changes in GRA and couple relocations over the life course 1118

$\begin{array}{lll}\text { 2.3.1 Why do gender role attitudes change after couple relocations? } & 1118\end{array}$

2.3.2 Heterogeneity in couple relocations and changes in GRA 1121

3 Method 1122

3.1 Data and sample $\quad 1122$

3.2 Measures 1123

3.2.1 Gender role attitudes (GRA) 1123

$\begin{array}{lll}3.2 .2 & \text { Couple relocations } & 1124\end{array}$

$\begin{array}{lll}3.3 & 1127\end{array}$

$4 \quad$ Results 1129

$\begin{array}{lll}5 & \text { Discussion and concluding remarks } & 1137\end{array}$

6 Acknowledgements 1140

$\begin{array}{ll}\text { References } & 1141\end{array}$

$\begin{array}{ll}\text { Appendix } & 1147\end{array}$ 


\title{
Changes in gender role attitudes following couples' residential relocations
}

\author{
Sergi Vidal ${ }^{1}$ \\ Philipp M. Lersch ${ }^{2}$
}

\begin{abstract}
BACKGROUND

Residential relocations of couple households are associated with increases in objective gender inequality within families in paid and unpaid work. Little is known about how couples' relocations affect subjective outcomes such as attitudes.
\end{abstract}

\section{OBJECTIVE}

We examine whether gender role attitudes change when families move residentially in Britain, empirically addressing potential explanations. We also assess heterogeneity in outcomes by relocation distance and relocation motive.

\section{METHOD}

We use linear fixed-effects regression on a representative sample of 6,415 partnered women and 6,220 partnered men from the British Household Panel Survey (19912007).

\section{RESULTS}

Our results show that, on average, an individual's gender role attitudes were not significantly altered following a couple's relocation. As an exception, we find that when couples exclusively relocated for the female partner's job, men's gender role attitudes became more egalitarian post-relocation. Preliminary evidence also suggests that women's gender role attitudes are potentially affected by their exposure to residential contexts.

\section{CONTRIBUTION}

Despite widespread evidence regarding increases in objective gender inequality following couple relocations in Britain, our findings suggest that this does not permeate into subjective outcomes such as attitudes. Beyond expanding the knowledge on subjective sources of gender inequality that follow couples' relocations, our results also

\footnotetext{
${ }^{1}$ Centre d'Estudis Demogràfics (CED), Barcelona, Spain. Email: svidal@ced.uab.es.

${ }^{2}$ Institute of Sociology and Social Psychology, University of Cologne, Germany.
} 
contribute to a better understanding of the dynamics of change in gender role attitudes over the life course.

\section{Introduction}

Recent decades have witnessed tremendous changes in how women and men behave and express their views regarding work and family life. Increases in egalitarian gender role attitudes, or the degree to which individuals support an equal division of labour between women and men, have been documented in a number of countries (including Britain) since the 1970s, particularly among women (Braun and Scott 2009; Cotter, Hermsen, and Vanneman 2011). Ideational changes regarding gender issues were paralleled by a pervasive structural de-traditionalisation of gender relations. These developments involved generalised delays and declines in marriage and fertility levels, alongside women's increasing educational attainment and participation in paid employment and men's rising employment instability and increasing involvement (though still incipient) in domestic work and childcare. In recent years, concurrent progress in egalitarian gender role attitudes and practices have stalled, and consequently, gender equality at home and at work remains elusive (England 2010).

Understanding the shifts and reversals in gender role attitudes is important because adherence to traditional gender role attitudes has been shown to contribute to the (re)production of gender inequalities over the life course (Corrigall and Konrad 2007; Christie-Mizell et al. 2007; van Gameren 2013). Recent studies have shown that individuals' gender role attitudes are malleable and context-dependent and have suggested that individuals re-evaluate these attitudes in relation to life course transitions that affect the negotiation of work and family roles (Cunningham 2005; Fan and Marini 2000; Schober and Scott 2012; Baxter et al. 2015; Perales, Lersch, and Baxter 2017). While strong evidence of the effects of union formation, parenthood, completion of education, and entry into employment on gender role attitudes already exists, there is much less evidence about the effects of other important life course events, such as couple relocations. This is a limitation, since couple relocations are expensive, disruptive, and thus often accompanied by changes in the household's family, employment, and residential circumstances and contexts, which are potentially relevant for the negotiation of gender roles (Cooke 2001; Vidal et al. 2017). Established findings from the empirical research indicate, among other things, that couples often relocate around the time of childbearing, that men more often lead job-related (long-distance) relocations than women do, and that these relocations almost exclusively benefit men's careers while women's careers are possibly held back (Boyle et al. 2003; Boyle, Feng, 
and Gayle 2009). Since these findings suggest that unequal gender divisions of household labour likely emerge or widen following couple relocations, a hypothetical association between gender role attitudes and couple relocations is reasonable. While gender role attitudes were examined as predictors of couple relocations and their outcomes (in, e.g., Cooke 2008a; Brandén 2014; Lersch 2016), to our knowledge, no previous study has investigated gender role attitudes as an outcome of couple relocations.

In this study, we close gaps in knowledge and shed light on additional sources of change in gender role attitudes by examining the role of couples' relocations in the British context between the 1990s and the 2000s. We address the following questions:

(1) Is there an association between couple relocations and changes in gender role attitudes?

(2) Does the association vary by relocation distance? And by relocation motive?

(3) What are the mechanisms that underlie these associations?

Extending prior research, we address, for the first time, a subjective measure of gender inequality - combining individuals' support to statements on mothers' employment and equal divisions of labour - as an outcome of couple relocations. This contributes to understanding the persisting gender inequalities that follow couple relocations in Britain (and elsewhere), which have only been addressed as objective rather than subjective inequality outcomes. In addition, we assess heterogeneity in the effect of relocations on attitudinal change by considering a number of distance- and motive-based relocation measures. Drawing on the life course framework and theoretical arguments for within-individual change in attitudes, we develop and test substantive explanations for the associations under study. We empirically address the above questions deploying linear fixed-effects regression on a representative sample of 6,415 partnered women and 6,220 partnered men from the British Household Panel Survey (BHPS; 1991-2007).

\section{Background}

\subsection{Study context}

Some aspects of the national context frame gender relations and residential relocations in Britain. Consistent with liberal political traditions, Britain's welfare system combines low, often targeted provision from the state with high reliance on a relatively flexible 
Vidal \& Lersch: Changes in gender role attitudes following couples' residential relocations

labour market to secure households' well-being (Esping-Andersen 1990). Although a consequence of this is high female labour force participation, the laissez-faire institutional approach and the relative persistence of cultural beliefs that endorse women's secondary earner roles lend little support to gender equality through women's employment (Cooke 2011). Gender inequalities accumulate over an individual's life course, with parenthood being the most salient factor leading to significant earnings and career penalties for British women but not for British men (Cooke 2014). Within the study period, state support to families with young children was limited to leave periods for mothers that were largely unpaid. ${ }^{3}$ Private childcare options were expensive to the average wage earner and full-time public childcare support inexistent (Thévenon 2011). While a maternal caregiver remains the widespread prototypical care ideal for young children, societal approval of paternal caregiving has been increasing. However, fathers' long work hours and negligible leave entitlements, when compared to mothers, seem to prevent fathers from taking a major role in housework and childcare (Cousins and Tang 2004). Given all this, part-time work (combined with grandparental childcare support) is a widespread choice among working mothers. Only partnered women with higher education and earnings are able to negotiate more egalitarian household arrangements (Sullivan and Gershuny 2016) and to return to full-time work (sooner) after childbirth (Dex, Ward, and Joshi 2008; Schober and Scott 2012).

Social polarisation and high income inequality - relative to other wealthy nations underlie British housing markets and regional structures. Home ownership in Britain is socially expected and widespread yet not universal (Mulder and Billari 2010). Young couples aspire to own a house, often as a means to access high-quality accommodation in desirable locations for raising children (Mulder 2006). A general pattern for housing with increasing age - except for older households - is to enter owner-occupancy and gain space (Clark and Huang 2003). ${ }^{4}$ This is particularly true for middle-class households that make the transition to parenthood and often move to leafy neighbourhoods in suburban and rural areas, which makes it particularly difficult for women to juggle work and family (Boterman and Bridge 2015). In Britain, there are relevant regional inequalities with regards to economic growth, and career opportunities are largely concentrated in regions with larger urban centres (Champion et al. 2007).

\footnotetext{
${ }^{3}$ Mothers were entitled to 40 weeks (18 weeks paid) maternity leave between 1990 and 2002 and 52 weeks (26 weeks paid) since 2003. In addition, mothers can take up to 13 weeks of unpaid parental leave (which can be transferred to the father) since 2000. Fathers are entitled to two weeks of paid paternity leave. Public childcare for children aged 0-2 during the study period was negligible (under 5\%). Information retrieved from the OECD Family Database: http://www.oecd.org/els/family/database.htm (accessed November 27, 2018).

${ }^{4}$ The rental market is not deemed an alternative for families with relatively stable earnings, since it features lower quality accommodation in publicly-owned housing reserved for those in need and privately-owned housing that often caters to single people and families with lower socio-economic profiles (Lersch and Dewilde 2015).
} 
Regional inequalities limit socio-economic mobility through relocations across regions (Nightingale, McCollum, and Ernsten 2017). In contrast, relocations within regions do not significantly contribute to social mobility (Nightingale, McCollum, and Ernsten 2017) arguably because relatively high levels of socio-economic residential segregation limit opportunities to move to better-off neighbourhoods and local areas (Nieuwenhuis et al. 2017). It is worth noting that subnational family geographies within Britain exist, with patterns of partnering, parenting, and mother's labour force participation aligning with regional gender cultures (Duncan and Smith 2002).

\subsection{Previous literature}

Our study is informed by two separate but interrelated literatures. The first literature examines how gender role attitudes (GRA from now on) vary over the life course and why they are importantly related to individuals' behaviours, opportunities, and life outcomes (Bolzendahl and Myers 2004).

Attitudes are defined as individuals' dispositions to react in favourable or unfavourable ways to objects, persons, institutions, or events (Ajzen 2005). Gender role attitudes are often conceptualised on a continuum that ranges from traditional to egalitarian views of the roles of men and women with regard to family and employment. Traditional GRA support an unequal division of household labour with a male provider and a female homemaker. ${ }^{5}$ Egalitarian GRA support an equal division of household labour, or that any existing couple specialisation in paid and domestic work should be independent of gender categories. Although GRA is a well-established concept, recent literature has deployed the broader concept of gender ideology, referring to a general system of beliefs about the roles of men and women in society (Davis and Greenstein 2009). In practice, the associated empirical research relies on measures that construct GRA in relation to several life dimensions (Zoch 2018). Recent research has also suggested that with the gradual demise of traditional gender ideologies, several forms of egalitarian ideologies have emerged (liberal egalitarianism, egalitarian familism, and flexible egalitarianism), and these vary markedly across countries and welfare systems (see Knight and Brinton 2017). Although people increasingly adhere to one or another form of egalitarian ideology, liberal egalitarianism - which repudiates views endorsing gender essentialism - remains the most common egalitarian ideology in Britain. Among all forms of egalitarian ideology,

\footnotetext{
${ }^{5}$ According to the 'doing gender' approach (West and Zimmermann 1987), traditional GRA can be explained as differences between men's and women's perceptions of the problem of reconciling work and family responsibilities in line with dominant norms. Men were traditionally ascribed the role of breadwinner, and women were traditionally ascribed the role of homemaker.
} 
liberal egalitarianism is the most straightforward end of a unidimensional spectrum of gender ideology in opposition to traditional gender ideology (Knight and Brinton 2017). Given this, adopting a standard methodological strategy of examining adherence to traditional GRA along a continuum from high to low is justified for the British case.

Until recently, widespread views of rigid attitudes over the life course prevailed in GRA research, whose dominant focus has been the scrutiny of long-term trends in attitudinal change across cohorts (Baxter et al. 2015). These aligned well with ideas that life experiences and socialisation at early ages are highly important for the formation of individuals' attitudes, while later-in-life attitudinal change is much more restricted (Krosnick and Alwin 1989). Challenging these views, recent research evidence drawing on longitudinal data sets hints at the existence of shifts in GRA with increasing age (Danigelis, Hardy, and Cutler 2007). One general explanation for this is offered by intra-cohort ageing theory, which draws on ideas of life course progression. This theory considers attitudes to be relatively malleable individual dispositions because of their nature as evaluative judgements subject to contextual influences. Attitudinal changes are often prompted by life course events and mediated through individuals' processes of learning, responses to experiences, and adaptability to changes in social circumstances.

Two main mechanisms emerge from this theory (Bolzendahl and Myers 2004; Jarallah, Perales, and Baxter 2016). First, an interest-based mechanism of lifetime attitudinal change proposes that changes in GRA are due to changes in people's interests regarding gender structures. Interest structures are flexible and change when they do not align with people's new life goals and circumstances. Second, an exposurebased mechanism of lifetime attitudinal change proposes that changes in GRA can be connected to people's exposures to new ideas and experiences regarding gender structures that question their own views.

Empirical research along these lines confirmed, for the United Kingdom, that shifts in GRA occur around critical life events that affect individuals' contexts and life circumstances. Studies have focused on changes in GRA around union formation, parenthood, completion of education, and entry into employment (Scott, Alwin, and Braun 1996; Cunningham 2005; Berrington et al. 2008; Schober and Scott 2012). The related evidence suggests that career-related transitions, such as women's attainment of higher educational levels or entry in full-time employment, are generally associated with decreasing adherence to traditional GRA. Indeed, a gender egalitarian context that supports female career advancement is in the interest of women who (or men whose partners) complete education or enter employment. Additionally, increasing numbers of women in educational and work contexts contribute to ideals of gender egalitarianism. In contrast, the transition to parenthood is associated with a shift to traditional GRA because the associated new household and social arrangements often increase the exposure to contexts and new practices that conform to gendered expectations. 
The second literature examines residential relocations of stable partnerships as a site for within-couple gender inequality in the labour market and in the division of household labour. Initially emerging in the United States, the bulk of the literature to date in Britain and elsewhere has focused on the labour market outcomes of longdistance relocations, as these are usually economically motivated and require adaptations to new environments. Concerning work, long-distance relocations of British couples are found to be associated with reduced employment rates, work hours, hourly wages, and occupational status for partnered women, while the opposite was found for partnered men or unpartnered women (Boyle et al. 2001; Clark and Huang 2006; Cooke et al. 2009; Boyle, Feng, and Gayle 2009). To explain this, the tied-migrant hypothesis proposes that in the context of a couple household, one spouse - the lead migrant, usually men - initiates the couple relocation to benefit his own career while the other partner - the tied migrant or trailing spouse, usually women - follows, often at the expense of her own career (Mincer 1978; Cooke 2008b).

Opposed theoretical views on the underlying role of gender in the tied-migrant hypothesis co-exist, and testing their empirical validity was the object of most research between the late 1990s and the mid-2000s (Smith 2011). On the one hand, dominant explanations based on human capital accounts implicitly assume symmetry in the effect of education, training, or work experience across men and women for couple relocation decisions. These explanations propose that gender differences in career investments before relocations underlie the decisions and outcomes of couple relocations. The average stronger labour market position or bargaining power of partnered men over partnered women is used to explain why couple relocations relate to potential gains in the career of the male partner only. On the other hand, critical views of the implicit gender symmetry of these models emerged and were supported with contrasting research evidence showing that men's careers were also more likely to benefit from couples' relocations than women's careers even when there were no differences in partners' capacities and bargaining power (Shihadeh 1991). These views underscored the role that persisting gendered social structures and traditional gender role attitudes had on separate spheres (Halfacree 1995; Cooke 2008a). The underlying rationale is that labour market resources of men and women do not have equal weight in family bargaining processes due to gender identity constructions of femininity associated with domestic roles and masculinity associated with provider roles (Halfacree 1995; Cooke 2008a). Partnered individuals attribute less importance to the education, training, or work experience of the female partner when they adhere to traditional gender role attitudes. Recent studies used measures of partners' pre-relocation GRA and showed how these had some effects on gender-asymmetric decisions and labour market outcomes of couple relocations (Brandén 2014; Lersch 2016). In Britain, men's (but not 
women's) egalitarian GRA are associated with lower female employment exits following couples' relocations (Lersch 2016).

Further substantive theoretical and empirical contributions to this literature are moving beyond the (job-bounded) tied-migrant hypotheses to focus on the wider processes underlying couple relocations (Bailey and Boyle 2004; Smith 2011). These are increasingly delving into the role of the family, which was largely neglected in the debate (Bailey and Boyle 2004; Cooke 2008b). Family behaviour and family relations are core motivations for why couples move and have important consequences for partners' practices. Relocations of families and those occurring at the time of childbearing are more prominently associated with decreasing women's labour market participation and increasing gaps in the division of household labour (Cooke 2003). Moves around the time of childbearing are often geared towards suburban or rural areas with tighter labour markets that bolster unequal divisions of household labour (Kley and Drobnič 2019). Family households often relocate to approach family ties outside the household that can provide support (Mulder 2018). These relocations often coincide with returns to known contexts, which can arguably alleviate some of the negative relocation consequences for trailing spouses (Cooke and Bailey 1999).

Overall, the family migration literature has largely contributed to demonstrating that, on average, couple relocations have disproportionate effects for the employment careers of male and female partners and that family-related processes and the expected roles and actual practices of men and women are important predictors of these. Almost no research has been devoted to the consequences of relocations for the couple's home life or the division of household labour (see an exception on housework in Australia: Vidal, Perales, and Baxter 2016). To our knowledge, no research has inquired to what extent the renegotiations of couples' arrangements around couple relocations impinge on the re-evaluation of GRA.

In this study, we combine both literatures and we propose that relocation experiences may influence the processes that shape individuals' GRA. We expect these associations to be relevant in the British context, where gender-asymmetric decisions and occupational outcomes of family migration are pervasive.

\subsection{Changes in GRA and couple relocations over the life course}

\subsubsection{Why do gender role attitudes change after couple relocations?}

Residential relocations, in general, and couple relocations, in particular, are critical life events that can have implications for individuals' re-evaluations of GRA. We elaborate on two main explanations, drawing on the literature discussed above. 
First, residential relocations are important adjustment processes to new social roles over the life course (Mulder and Hooimeijer 1999). Relocations are often challenging, disruptive, and expensive and, hence, often (particularly for long-distance relocations) occur in tandem to other important life events, such as gaining new employment, giving birth, or buying a home (Clark and Davis Withers 2009; Bailey 2009). The changes in life circumstances around the time of relocations, which are expected, often affect individuals' negotiation of work and family roles, leading to new arrangements and practices. Couple relocations support such processes in that couples often move to new housing and locations to adjust to family needs ${ }^{6}$ or to be closer to the location of a new job, typically the male partner's. In line with interest-based explanations of attitude change, GRA may change after relocations through adjustments in attitudes to new interests that individuals develop alongside changes in life circumstances. On the one hand, life course events that often induce or relate to gendered practices such as parenthood, marriage, or female exits from the labour market are known to be associated with increases in traditional GRA. On the other hand, life course events such as obtaining higher education credentials or female entries in the labour market are known to be associated with increases in egalitarian GRA. Along these lines, we propose that life course transitions around the time of couple relocations act as confounders of the association under study. Thus, we expect that:

Hypothesis 1 (Life course adjustment hypothesis) The association between family relocations and GRA is a product of life course transitions occurring around family relocations.

Second, relocations often equate to changing local and social contexts. This may result in exposure to practices and values that were not widespread in previous contexts. According to exposure-based explanations of attitude change, GRA may change after relocations through opportunities embedded in new environments that change a person's own practices, as well as contact with new ideas that challenge their views. Research from institutional and cultural contexts similar to the British setting point in that direction. Empirical evidence from the United States suggests that individuals who relocate to new contexts often adapt their attitudes to those that are dominant in the new location (Barrett 2013). Research from Canada found that exposure to owned dwellings, larger dwellings, and suburban or rural areas were related to conservative attitudes (Verberg 2000; Walks 2004). It is also worth noting that given variations in structural opportunities, new contexts affect the partners' practices that feed individuals' ideologies. For instance, in Australia couple relocations into non-urban

\footnotetext{
${ }^{6}$ A common finding is that after or in preparation to childbearing, couples move to larger houses, better
} neighborhoods, and closer to relatives for raising children (Vidal, Huinink, and Feldhaus 2017). 
areas and larger dwellings were found to be associated with increases in female housework hours and in unequal gender divisions of household labour (Vidal, Perales, and Baxter 2016). Relocating to suburban or rural areas can also affect partners' time use by reducing access and proximity to childcare and workplaces. Research from the United States shows that relocations to the outskirts of cities around the time of childbirth increased the distance between home and the workplace considerably and constrained the job search, particularly among women (MacDonald 1999). Along these lines we propose that the new home and residential environments where couples relocate act as mediators of the study associations. ${ }^{7}$ Thus, we expect that:

Hypothesis 2 (Context adaptation hypothesis): Changes in the type of family dwelling and residential context will channel the association between couple relocations and GRA.

We cannot rule out the possibility that relocation decisions could be affected by individuals' dispositions to attitudinal change. People who change residential context are often deemed to be more adaptable to change than those who stay put. Recent evidence from Germany suggests that, all else equal, individuals' openness to move partly explains upward social mobility and improvements in quality of life associated with moving beyond the local and social context that people know (Huinink, Vidal, and Kley 2014). Such dispositional flexibility also affects attitudinal flexibility, and we suspect that this mechanism could also apply in the British context. As explained below, in our empirical application we will deploy a fixed-effects model that cancels out the effects of time-constant omitted variables, such as openness to moving and other personal dispositions related to flexibility in attitudes. In addition, relocations may be due to a prior change in GRA, which is commonly known as a feedback effect. The adjustment of local context could be motivated by opportunities elsewhere to make one's attitudes consistent with one's practices and behaviour. This may often occur where the average context of GRA no longer fits one's own beliefs. Relocations to spacious family dwellings in rural or suburban areas where traditional GRA pervade might be more likely after individuals' GRA become more traditional. In contrast, after individuals' GRA become more egalitarian, relocations might more often be directed towards areas with career opportunities for the male and female partners, where egalitarian GRA usually prevail. Although family and career events occurring around

\footnotetext{
${ }^{7}$ We note that life course transitions around couple relocations also have an impact on the social environment (e.g., parenthood increases socialisation with, and exposure to the attitudes of, other parents), but we consider that this effect is partly channeled through, and difficult to separate from, interest-based mechanisms of attitude change. For instance, relocations around the time of family transitions are often directed towards nonurban areas and relate to the adjustment of dwelling size or to entering owner-occupancy (Clark and Huang 2003).
} 
relocations might induce pre-relocation changes in GRA, adjusting for life course events in our analysis cannot rule out a possible feedback effect due to influential exposures (e.g., experiences) that we cannot observe. Feedback effects are not cancelled out in standard fixed-effects models, but we will offer preliminary evidence for the existence of feedback effects in a sensitivity analysis.

\subsubsection{Heterogeneity in couple relocations and changes in GRA}

The level and direction of change in GRA can be heterogeneous, as are the scope and motives underlying the context change after relocations. The distance of the relocation is often used as a marker for the scope of the context change. Long-distance relocations are considered to have larger impacts on the context change than short-distance relocations, including the need to change workplace, other daily activities, and face-toface social contacts. Additionally, the family migration literature in Britain (and elsewhere) indicates that pervasive changes in the gender division of labour are usually related to long-distance relocations (Boyle, Feng, and Gayle 2009; Lersch 2016). Although short-distance relocations often occur around the time of childbearing or to adjust housing to recent changes in family size and thus potentially affect individuals' attitudes, on average, such moves have a more limited effect on daily arrangements and social context. Therefore, we expect that:

Hypothesis 3 (Relocation distance hypothesis): Changes in GRA associated to couple relocations are more salient in longer- than shorter-distance relocations.

Additional heterogeneity in the motivation of context change can be assessed through relocation motives. Previous research suggests that oft-cited motives do not necessarily align with the distance of the relocation as expected by theory, e.g., noneconomic motives are often reported after a long-distance move (Morrison and Clark 2011). Consistent with the above explanations, relocations motivated by family and household circumstances such as having a(nother) child can be associated with individuals adopting family roles relating to gendered practices. Likewise, relocations geared towards family-friendly contexts where gendered practices and values are more widespread can be related to increases in traditional GRA. ${ }^{8}$ Regarding career related motives, the literature emphasises that gender inequalities following couple relocations

\footnotetext{
${ }^{8}$ Family motives can also relate to relocations near family members and these may be associated with the adoption of more or less traditional attitudes of such family ties. In a preliminary sensitivity analysis, we did not find evidence that a proxy for maternal GRA (mother's employment when respondent was age 14) mattered more for family motives than for other motives to explain shifts in GRA after relocations.
} 
are a direct or indirect consequence of the traditional family migration model, with men pursuing relocations that benefit their careers (lead migrant) and women following their partners (tied migrant), often at the expense of their careers (Boyle, Feng, and Gayle 2009). We note that such a model may lead to increases in traditional GRA because of the associated couple specialisation following a relocation. In addition, increasing numbers of couple relocations are led by women who pursue careers; often these relocations are in tandem with improvements (or with no penalties) for the careers of both partners. As long as these moves are likely to improve or not affect women's resources (in relation to men's) for negotiating the division of household labour, changes in GRA after couple relocations, if observed, should be towards less traditional GRA. Along these lines, we set some further expectations combining the job-related relocation reasons of both partners. We expect that:

Hypothesis 4 (Male-led mover hypothesis): Couple relocations exclusively for the male partner's job are associated with more traditional GRA after couple relocations.

In contrast, we expect that:

Hypothesis 5 (Female-led or co-led mover hypothesis): Couple relocations exclusively for the female partner's job or for both partners' jobs are associated with less traditional GRA after couple relocation.

\section{Method}

\subsection{Data and sample}

For the empirical analysis we exploit the longitudinal and multi-actor dimensions of the British Household Panel Survey (BHPS). The BHPS is a multipurpose study that annually interviewed all adult members from a representative sample of households in the United Kingdom from 1991 until 2008. The original sample consisted of around 10,000 individuals in 5,500 households. We use two regional booster samples that were added to the survey in 1999 for Scotland and Wales (1,500 households) to enable the analysis of representative samples of the population of these subnational entities. Sample attrition in the BHPS is similar to other household panel surveys, with about $48 \%$ of original respondents being interviewed again in 2008 (Taylor et al. 2010). Our outcome of interest, GRA, is only measured every other year from 1991-2007. 
The BHPS is well-suited for our analysis because it allows the tracking of individuals over time, taking into account their nesting within couples, families, and regions. Furthermore, it regularly collected information on a number of key variables for our analysis, including attitudes on gender issues, residential mobility (relocation distance and motivations), and life course transitions in employment, family, and housing domains. Previous research shows that tracking long-term changes in GRA over time is feasible using BHPS (e.g., Schober and Scott 2012). Prior use of this data set also highlights how its large sample size offers a unique opportunity to target specific subpopulations, such as couples relocating over long distances, and to address dyadic mechanisms, such as couple bargaining (e.g., Taylor 2007; Perales and Vidal 2013; Lersch 2016).

To examine the associations between couples' residential mobility and changes in GRA, we draw a sample of adult individuals (between ages 18 and 64) in heterosexual couples who are either the head of household or his/her partner $(n=15,544$ respondents; $\mathrm{n}=123,880$ observations). We use original sample respondents as well as those from the Scotland and Wales extensions. To address change in GRA, we exclude 61,382 observations (and 819 respondents) from even-numbered survey years, when information on GRA was not collected. We additionally discard 12,213 observations (and 2,909 respondents) with incomplete information on model variables or from

individuals who do not report information on GRA on at least two occasions. ${ }^{9}$ Our analytical sample consists of an unbalanced panel that comprises 50,285 observations from 6,415 women and 6,220 men.

\subsection{Measures}

\subsubsection{Gender role attitudes (GRA)}

The outcome under study is adherence to traditional GRA, which is traditionally approximated by the degree of agreement with normative statements about the consequences of mothers' employment for families and the division of household labour between men and women. Every second year, the BHPS ask participants to indicate their agreement with three statements on these issues using 5-point Likert scales $[1=$ strongly agree; $5=$ strongly disagree $]$ :

\footnotetext{
${ }^{9}$ Relevant model variables contributing to dropping observation were housework hours (about $10 \%$ missing) and partner's work hours (about 5\% missing). Excluding these variables from models renders no substantive changes in the overall conclusions of the presented results.
} 
(1) "A preschool child is likely to suffer when the woman has a full-time job";

(2) "All in all, family life suffers when the woman has a full-time job";

(3) "A husband's job is to earn money; a wife's job is to look after the home and the family."

We use these statements to generate a composite measure of GRA. These three items show a strong internal consistency $($ alpha $=0.78)$, suggesting a high reliability of a composite measure to approximate a latent construct of GRA. Following Lersch (2016), we construct the composite measure by recoding the responses $(-2=$ strongly agree; 2 = strongly disagree) and calculating their mean scores across the three items. The resulting variable takes positive values (disagreement with the statements) for nontraditional GRA and negative values (agreement with the statements) for traditional GRA. We additionally z-standardise the composite measure (i.e., subtracting its mean and dividing by its standard deviation) to ease the interpretation of the effect sizes and enable comparisons with other studies. In our sample, the standardised GRA measure takes a mean value of 0 (as the non-standardised measure equally does), within a range from -2 to 2 and a standard deviation of 1 . On average, men are more traditional $($ GRAmen $=-0.170)$ and women are less traditional $($ GRAwomen $=0.119)$, and the difference across genders is statistically significant (GRAwomen-GRAmen $=0.289$, $p<.01)$.

We note that BHPS contains additional statements that some research has used to measure GRA, but these were discarded because the attitudes they capture are conceptually unclear and they substantially reduce the reliability of a composite GRA measure (Schober and Scott 2012). In fact, results from exploratory factor analysis shows that the three additional statements loaded on a distinct factor (Lersch 2016). ${ }^{10}$

\subsubsection{Couple relocations}

We use information available in the BHPS on individuals' residential change since the previous interview round. As is standard in the literature, we only consider relocations between houses when both partners move as a couple household and discard relocations in which either one or both partners move in or out of the couple household. In our

\footnotetext{
${ }^{10}$ The three additional statements read: "A woman and her family would all be happier if she goes to work"; "Both the husband and the wife should contribute to household income"; and "Having a full-time job is the best way for a woman to be an independent person". We note that results remain virtually unchanged when these additional items are considered in our GRA measure. As an exception, a few additional statistically significant coefficients for relocation indicators appear, with men becoming slightly more traditional after short relocations that are dwelling- or context-motivated.
} 
sample, 2,701 women and 2,621 men - four in ten female and male respondents report couple household relocations over the complete observation period (see Table 1).

We construct motive-based and distance-based measures of residential relocations. If respondents moved, they are further asked whether the motive of the move related to their own job (Did you move for reasons that were wholly or partly to do with your own job or employment opportunities?) and to name two main relocation motives (What were your (other) main reasons for moving?) in an open-ended question that were coded into 30 categories relating to diverse factors, such as family, employment, housing, and neighbourhood, among others. We consider four types of relocation motives measured at the individual level. First, job-related relocations are defined as moves where the respondent indicated that the move was related to her/his job (or training) in any of the above questions. Second, family-related relocations are defined as moves where the respondent indicated family events or being geographically closer to family or close friends as one relocation motive. Third, context-related relocations are defined as moves where the respondent indicated aspects of the dwelling or the residential area as one relocation motive. Four, respondents may have provided motives not aligned with any of the above and, thus, are categorised in the miscellaneous group of other motives. While almost all respondents named relocation motives, only about $15 \%$ of the respondents named two main motives. We note that several respondents provide more than one type of motive for the same relocation, but results are not affected when these cases are excluded from the analysis.

In addition, we combine job-related relocations from the male and the female partners to exploit couple-level dynamics regarding job-related couple relocations, as well as which partner's job benefited from relocating. We consider four possible combinations: relocations exclusively motivated by the male partner's job, relocations exclusively motivated by the female partner's job, relocations motivated by the jobs of both partners simultaneously, and relocations not motivated by either partner's job. These combined job-related relocations allow us to address gender symmetry in jobrelated relocation decisions, which has been identified as a key driver of gender inequality following couples' relocations.

If respondents moved, the BHPS team computed the distance between the present and former location. We consider two types of relocations based on the distance moved, following conventions in the literature. First, short-distance relocations are defined as moves of less than 50 kilometres. Second, long-distance relocations are defined as moves of 50 kilometres or more. Long-distance relocations are more often associated with changes in employment and the disruption of other daily activities and arrangements than with short-distance relocations. This is why long-distance relocations are assumed to have a larger influence on couples' renegotiations of the divisions of household labour. 
For each type of relocation measure, we construct indicator variables that take the value 1 for all observations of an individual after a relocation was reported within the observation window and 0 for all observations of an individual before a relocation was reported. The examination of differences in GRA before and after the relocation enables the estimation of the overall change in GRA that is related to the relocation. As couples can move more than once throughout the observation window, we construct an indicator variable for frequent relocations that takes the value 1 if more than one relocation was observed in the study window at a given survey wave and 0 otherwise. To acknowledge the fact that the most recent moves may have a greater impact than earlier moves, we construct an indicator variable that takes the value 1 if more than two years have elapsed since the last relocation was observed and 0 otherwise. Table 1 summarises the prevalence of each type of relocation within our sample. Most relocations cover shorter rather than longer distances and are due to motives relating to housing and the residential area. We note that discrepancies on frequencies across motive- and distance-based relocation types in Table 1, with larger frequencies for motive- than distance-based relocation types, are due to some respondents providing more than one motive for a relocation. About half of those who relocated once also relocated a second or more times (not shown in Table 1).

\section{Table1: Couple relocations by type and gender}

\begin{tabular}{lrrrr}
\hline & \multicolumn{2}{c}{ Women } & \multicolumn{2}{c}{ Men } \\
& Frequency & \multicolumn{1}{c}{$\%$} & Frequency & \multicolumn{1}{c}{$\%$} \\
\hline $\begin{array}{l}\text { Relocation } \\
\text { Relocation distance }\end{array} \quad 2,701$ & 42.1 & 2,621 & 42.1 \\
$\quad$ Short distance & & & & \\
$\quad$ Long distance & 2,473 & 38.6 & 2,385 & 38.3 \\
$\quad \begin{array}{l}\text { Relocation motives } \\
\quad \text { Individual motives }\end{array}$ & 490 & 7.6 & 485 & 7.8 \\
$\quad$ & & & & \\
$\quad$ for job & & & 537 & 8.6 \\
$\quad$ for family & 522 & 8.1 & 705 & 11.3 \\
$\quad$ for housing/area & 802 & 12.5 & 1,895 & 30.5 \\
$\quad$ for other reasons & 2,029 & 31.6 & 437 & 7.0 \\
$\quad$ Combined job motives & 398 & 6.2 & & \\
$\quad$ for the job of both & & & 306 & 4.9 \\
$\quad$ for his job & 320 & 5.0 & 142 & 2.3 \\
$\quad$ for her job & 135 & 2.1 & 102 & 1.6 \\
$\quad$ for the job of none & 110 & 1.7 & 2,132 & 34.3 \\
Overall (N) & 2,214 & 34.5 & 6,220 & 100.0 \\
\hline
\end{tabular}

Note: 'Frequency' refers to number of individuals. Combined job motives use responses of the male partner and female partner on job-related relocation responses and only when both respondents provide responses on relocation motives.

Data: BHPS 1991-2007. 


\subsection{Empirical strategy}

We first show the descriptive results of crude change in GRA before and after relocations across motive-based and distance-based relocation measures. We then address these associations in a multivariate context estimating linear fixed-effects regression models. Fixed-effects regression leverages repeated observations on study subjects to estimate within-subject differences in the response variable as a function of within-subject differences in explanatory variables. In our model, estimates of withinsubject differences reflect changes in GRA - the response variable - before and after relocations, the explanatory variable. The model to be estimated can be written as:

$A_{i t}-\bar{A}_{i}=\left(R_{i t}-\bar{R}_{i}\right) \beta+\left(X_{i t}-\bar{X}_{i}\right) \omega+\left(e_{i t}-\bar{e}_{i}\right)$,

where subscripts $i$ and $t$ stand for respondent and time, respectively; $A$ is the GRA measure; $R$ is a vector of variables capturing motive-based and distance-based relocations (specified in different models); $X$ is a vector of additional time-varying variables; $\beta$ and $\omega$ are vectors of estimated coefficients; and $e$ is the stochastic error term. This is a within-subject transformed equation - subtracting subject-specific means from the parameter elements of the equation - and can be estimated using a standard regression model. As a result of the within-subject transformation, time-constant variables (e.g., gender or ethnicity) are cancelled out in the equation and thus their associations with the response variable cannot be estimated but are effectively controlled for. In a similar vein, unobserved time-constant factors potentially correlated with the explanatory, and response variables are also cancelled out in the equation, reducing the associated omitted variable bias. Among others, these omitted variables may include stable individual dispositions, such as personal traits. We note that omitted variable bias due to time-varying unobserved or unobservable sources may remain.

We fit separate models for men and women to address gender-specific associations. ${ }^{11}$ Given that our sample contains a large number of heads of household and their partners, whose behaviour and attitudes are likely correlated, separated models for men and women also limit violations to the model assumption of independence across observations. To test our hypotheses on the heterogeneity in the associations we fit motive-based measures (Hypothesis 4: Male-led mover hypothesis and Hypothesis 5: Female-led or co-led mover hypothesis) and distance-based measures (Hypothesis 3: Relocation distance hypothesis) in different models.

\footnotetext{
${ }^{11}$ Changes in GRA associated with couple relocations could have a different relevance for women than for men, as couple relocations are associated with more profound changes in the roles and practices of women than those of men. Women often take on the lion's share of childcare and domestic work and often reduce their employment hours after relocations.
} 
To test our hypotheses about observed factors confounding (Hypothesis 1: Life course adjustment hypothesis) or mediating (Hypothesis 2: Context adaptation hypothesis) the associations under study, we estimate nested models with stepwise inclusion of relevant control variables:

- Model 1 includes motive- or distance-based relocation variables, in addition to respondent's age (four categories to assess non-linear associations: ref. 18-29, 30-39, 40-49, and 50-64), indicators for each calendar year (ref. 1993), and the above commented indicators for recent relocations.

- Model 2 adds control variables capturing relevant life course triggers in family and work domains to Model 1: an indicator for whether the respondent is legally married and an indicator combining the presence and age of non-adult children in the respondent's household (i.e., one indicator for whether there are children under 5 years of age in the household and one indicator for whether there are children between 5 and 17 years of age in the household), a household income measure (deflated, in 1991-equivalent pounds, and logtransformed), an indicator for respondent's weekly housework hours (10 or more hours a week; ref. less than 10 hours), ${ }^{12}$ and indicators for the respondent's and partner's employment status and usual weekly paid work hours ( 35 or more hours a week; ref. less than 35 hours).

- Model 3 adds control variables capturing housing and residential environments to Model 2: an indicator for whether the respondent is in owner-occupancy, an interval measure of the number of bedrooms in the home, and an indicator for residence in an urban area.

In the results section we comment on changes in the size and statistical significance of the coefficients for relocation indicators and the additional model covariates. Since the GRA measure is standardised, the size of coefficients is interpreted as a percentage change in GRA by a unit change in the model variable. Despite not being a conventional level of statistical significance, we consider coefficients to be marginally significant if they are in the $90 \%$ level of statistical significance given that fixed-effects models render conservative standard errors. We used Stata 14.0 for the analyses and the official command xtreg for the fixed-effects regression. Summary statistics of model covariates can be consulted in Table A-1 in the Appendix.

\footnotetext{
${ }^{12}$ Additional measures of partner's housework hours and respondent and partner's care hours were available but discarded due to their high levels of non-response. Sensitivity analyses including these variables in the models rendered no substantive change in the overall conclusions from model results.
} 


\section{Results}

Figure 1 plots the distributions and mean value of GRA by sex across two groups of observation, where a relocation has been observed and where a relocation has not (yet) been observed since the study began. The plotted distributions are Kernel-smoothed density functions of GRA values adjusted by age. Results in Figure 1 show that for both men and women, respondents reporting a relocation are distributed along less traditional values of GRA than respondents not (yet) reporting a relocation. A small $p$ value associated with a test of differences in mean statistically supports this.

\section{Figure 1: Age-adjusted gender role attitudes (GRA) before and after couple relocations by sex}

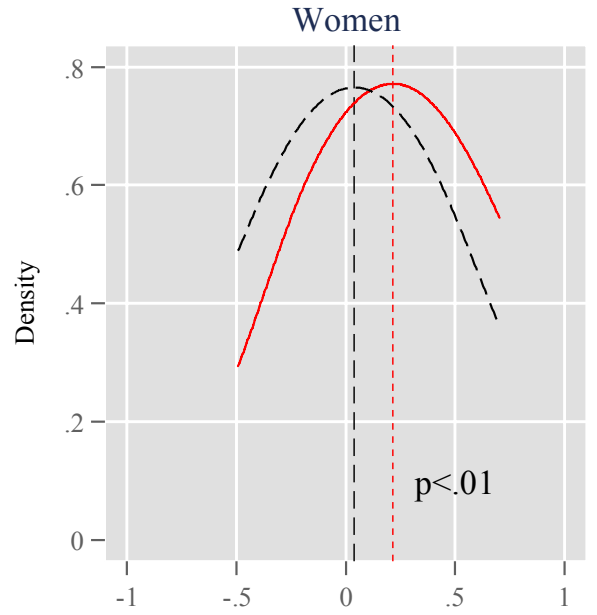

GRA - egalitarian gender ideology

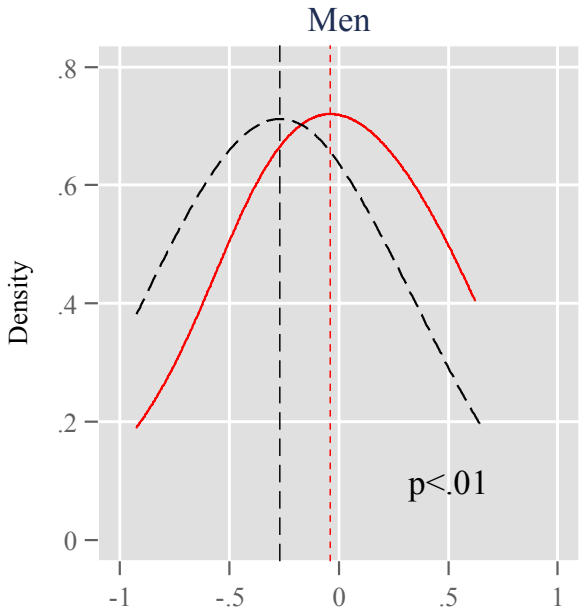

GRA - egalitarian gender ideology
- Relocation

- - No Relocation
- Relocation

- - No Relocation

Note: Density function of the composite measure of GRA (z-standardised) is based on weighed OLS regression and residualised on age. Positive values of GRA denote adherence to more egalitarian GRA and negative values of GRA denote adherence to more traditional GRA. 'Relocation' are observations of respondents reporting one or more relocations, and 'No Relocation' are observations of respondents reporting no relocations since their first participation in the study. The density functions have been smoothed using a Kernel estimator. Vertical lines are mean coefficients of the GRA measure. $P$-value is the probability of a Tstudent's two-tailed test for equality of GRA means across Relocation and No Relocation groups.

Data: BHPS 1991-2007.

We now turn to describe differences by the type of move. Figure 2 displays average standardised GRA values adjusted by age and $95 \%$ confidence intervals across groups of observations where motive- or distance-specific relocations have been 
reported. Results of Figure 2 show that for both men and women, any type of relocation is associated with less traditional GRA than not having (yet) relocated. Figure 2 shows few significant differences in GRA across types of relocations. Regarding the distance of the relocation, we find no statistically significant differences in GRA across shortdistance and long-distance relocations. Regarding individual respondents' relocation motives, less traditional GRA were found among men and women moving for familyrelated motives. Additional bivariate analyses (not shown) indicate that individuals reporting family motives display more typical profiles of egalitarian GRA - such as living/moving to an urban area and having an employed mother when they were age 14 - than individuals reporting other motives. This is suggestive of egalitarian individuals being more inclined to take relevant household decisions for the sake of the family than for (their own) careers. Despite this, job-related reasons are the second most important relocation motive associated with less traditional gender ideology, particularly among women. This was expected, since egalitarian women are more likely to pursue careers than traditional women. Despite this, in the combined partner job motives, we do not find that women are less traditional if the couple moves for her job or the job of both partners than if the couple moves for his job. Similarly, men display less traditional gender ideology when moving for her job or the job of both than when moving for his job, but differences in average gender ideology across groups are not statistically significant.

These results show evidence of couple relocations being associated with GRA, but these have two possible interpretations: Differences are between subjects, with individuals who relocate being more egalitarian than individuals who do not relocate, or differences are within subjects, in that individuals change their attitudes, adhering to less traditional gender ideology after relocations. We now address the extent to which respondents change their GRA after relocations and possible explanations for this in the fixed-effects regression models. 
Figure 2: $\quad$ Age-adjusted gender role attitudes (GRA) before and after couple relocations by type of relocation and sex
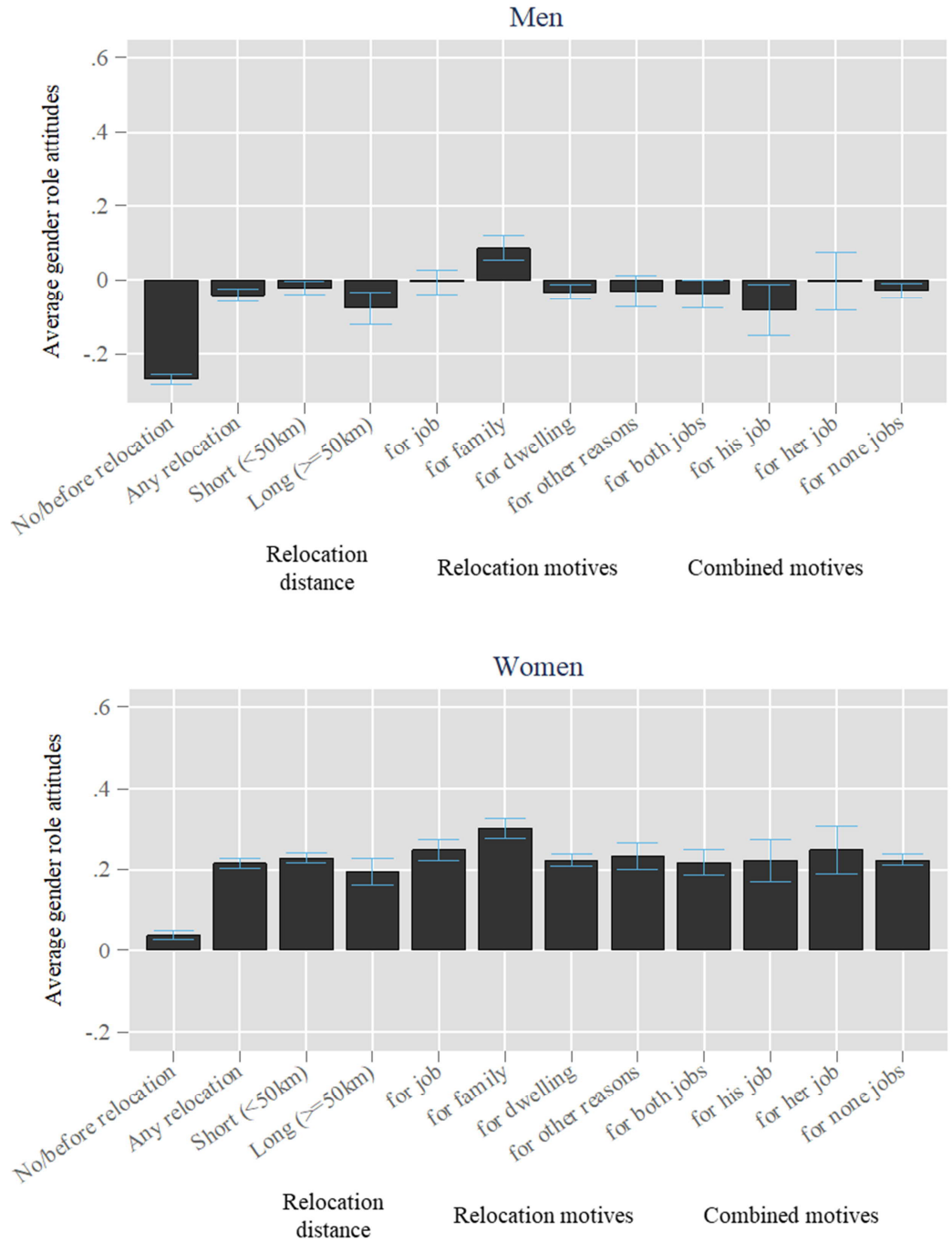

Note: Mean coefficients of the composite measure of GRA (z-standardised) are based on weighed OLS regression and residualised on age. Positive values of GRA denote adherence to less traditional GRA and negative values of GRA denote adherence to more traditional GRA. 95\% Cl stands for 95\% confidence interval values. 'Combined motives' use responses of the male partner and female partner on job-related relocation responses and only when both respondents provide responses on relocation motives. Data: BHPS 1991-2007. 
Table 2 displays gender-specific model coefficients of percent changes in the GRA measure associated with a one-unit change in the overall relocation indicator coefficient and other model variables. In Model 1 , in addition to the relocation indicator, we adjusted only for respondent's age, relocation timing (2+ years since relocation), and relocation frequency (more than one relocation) indicators. Therefore, we use results from this base model as a sophisticated description of change in GRA after couple relocation. Results from Model 1 reveal that changes in GRA after overall couple relocations are insignificant, as model coefficients were generally small - below 5\% change in GRA - and statistically non-significant for both women $(\beta=0.02, p>0.05)$ and men $(\beta=-0.01, p>0.05)$. Frequent relocations are associated with marginal changes in GRA among women but not among men. A negative coefficient that is modest but statistically significant $(\beta=-0.05, \mathrm{p}<0.05)$ suggests that women's GRA are $5 \%$ more traditional with frequent couple relocations. Duration since relocation has a (near-)zero coefficient for both men and women. Respondent's age is associated with increases in traditional GRA among men but unrelated to shifts in women's GRA.

Table 2: Within-subject change in GRA after couple relocations (multivariate models)

\begin{tabular}{|c|c|c|c|c|c|c|}
\hline & \multicolumn{3}{|c|}{ Men } & \multicolumn{3}{|c|}{ Women } \\
\hline & $\begin{array}{c}\text { Model } 1 \\
\text { B/(SE) }\end{array}$ & $\begin{array}{c}\text { Model } 2 \\
\text { B/(SE) }\end{array}$ & $\begin{array}{c}\text { Model } 3 \\
\text { B/(SE) }\end{array}$ & $\begin{array}{c}\text { Model } 1 \\
\text { B/(SE) }\end{array}$ & $\begin{array}{c}\text { Model } 2 \\
\text { B/(SE) }\end{array}$ & $\begin{array}{c}\text { Model } 3 \\
\text { B/(SE) }\end{array}$ \\
\hline \multicolumn{7}{|l|}{ No/before relocation (ref.) } \\
\hline Relocation & $\begin{array}{c}-0.01 \\
(0.02)\end{array}$ & $\begin{array}{c}-0.00 \\
(0.02)\end{array}$ & $\begin{array}{c}0.01 \\
(0.02)\end{array}$ & $\begin{array}{c}0.02 \\
(0.02)\end{array}$ & $\begin{array}{c}0.02 \\
(0.02)\end{array}$ & $\begin{array}{c}0.03 \\
(0.02)\end{array}$ \\
\hline Frequent relocations & $\begin{array}{c}-0.01 \\
(0.02)\end{array}$ & $\begin{array}{c}-0.01 \\
(0.02)\end{array}$ & $\begin{array}{c}-0.01 \\
(0.02)\end{array}$ & $\begin{array}{c}-0.05^{*} \\
(0.03)\end{array}$ & $\begin{array}{c}-0.05+ \\
(0.03)\end{array}$ & $\begin{array}{c}-0.04 \\
(0.03)\end{array}$ \\
\hline Two or more years since relocation & $\begin{array}{c}0.01 \\
(0.02)\end{array}$ & $\begin{array}{c}0.00 \\
(0.02)\end{array}$ & $\begin{array}{c}0.00 \\
(0.02)\end{array}$ & $\begin{array}{c}-0.00 \\
(0.02)\end{array}$ & $\begin{array}{c}-0.00 \\
(0.02)\end{array}$ & $\begin{array}{c}-0.01 \\
(0.02)\end{array}$ \\
\hline Age 30-39 (ref. 18-29) & $\begin{array}{c}-0.08^{\star *} \\
(0.02)\end{array}$ & $\begin{array}{c}-0.08^{* *} \\
(0.02)\end{array}$ & $\begin{array}{c}-0.08^{\star *} \\
(0.02)\end{array}$ & $\begin{array}{c}-0.00 \\
(0.02)\end{array}$ & $\begin{array}{c}0.00 \\
(0.02)\end{array}$ & $\begin{array}{c}0.01 \\
(0.02)\end{array}$ \\
\hline Age $40-49$ & $\begin{array}{l}-0.12^{\star *} \\
(0.03)\end{array}$ & $\begin{array}{l}-0.14^{* *} \\
(0.03)\end{array}$ & $\begin{array}{c}-0.14^{\star *} \\
(0.03)\end{array}$ & $\begin{array}{c}-0.04 \\
(0.03)\end{array}$ & $\begin{array}{c}-0.05+ \\
(0.03)\end{array}$ & $\begin{array}{c}-0.05 \\
(0.03)\end{array}$ \\
\hline Age $50-64$ & $\begin{array}{c}-0.13^{\star *} \\
(0.04)\end{array}$ & $\begin{array}{c}-0.15^{\star *} \\
(0.04)\end{array}$ & $\begin{array}{c}-0.14^{* *} \\
(0.04)\end{array}$ & $\begin{array}{c}-0.05 \\
(0.04)\end{array}$ & $\begin{array}{c}-0.06 \\
(0.04)\end{array}$ & $\begin{array}{c}-0.06 \\
(0.04)\end{array}$ \\
\hline Married & & $\begin{array}{c}-0.00 \\
(0.02)\end{array}$ & $\begin{array}{c}-0.00 \\
(0.02)\end{array}$ & & $\begin{array}{c}-0.03 \\
(0.03)\end{array}$ & $\begin{array}{c}-0.03 \\
(0.03)\end{array}$ \\
\hline Children under 5 & & $\begin{array}{c}0.02 \\
(0.02)\end{array}$ & $\begin{array}{c}0.03 \\
(0.02)\end{array}$ & & $\begin{array}{c}0.01 \\
(0.02)\end{array}$ & $\begin{array}{c}0.02 \\
(0.02)\end{array}$ \\
\hline Children 5-17 & & $\begin{array}{c}-0.03 \\
(0.02)\end{array}$ & $\begin{array}{c}-0.03 \\
(0.02)\end{array}$ & & $\begin{array}{c}-0.04+ \\
(0.02)\end{array}$ & $\begin{array}{c}-0.04+ \\
(0.02)\end{array}$ \\
\hline Household (log-) income & & $\begin{array}{c}0.01 \\
(0.01)\end{array}$ & $\begin{array}{c}0.01 \\
(0.01)\end{array}$ & & $\begin{array}{c}0.01 \\
(0.01)\end{array}$ & $\begin{array}{c}0.01 \\
(0.01)\end{array}$ \\
\hline Employed & & $\begin{array}{c}-0.03 \\
(0.02)\end{array}$ & $\begin{array}{c}-0.03 \\
(0.02)\end{array}$ & & $\begin{array}{c}0.10^{\star *} \\
(0.02)\end{array}$ & $\begin{array}{c}0.10^{\star *} \\
(0.02)\end{array}$ \\
\hline
\end{tabular}


Table 2: (Continued)

\begin{tabular}{|c|c|c|c|c|c|c|}
\hline & \multicolumn{3}{|c|}{ Men } & \multicolumn{3}{|c|}{ Women } \\
\hline & $\begin{array}{l}\text { Model } 1 \\
\text { B/(SE) }\end{array}$ & $\begin{array}{l}\text { Model } 2 \\
\text { B/(SE) }\end{array}$ & $\begin{array}{l}\text { Model } 3 \\
\text { B/(SE) }\end{array}$ & $\begin{array}{l}\text { Model } 1 \\
\text { B/(SE) }\end{array}$ & $\begin{array}{l}\text { Model } 2 \\
\text { B/(SE) }\end{array}$ & $\begin{array}{l}\text { Model } 3 \\
\text { B/(SE) }\end{array}$ \\
\hline Usual work hours ( $\geq 35$ hours/week) & & $\begin{array}{c}0.01 \\
(0.02)\end{array}$ & $\begin{array}{c}0.01 \\
(0.02)\end{array}$ & & $\begin{array}{c}0.03^{*} \\
(0.02)\end{array}$ & $\begin{array}{l}0.03+ \\
(0.02)\end{array}$ \\
\hline Partner: Employed & & $\begin{array}{l}0.11^{\star *} \\
(0.02)\end{array}$ & $\begin{array}{l}0.11^{* *} \\
(0.02)\end{array}$ & & $\begin{array}{l}-0.03 \\
(0.02)\end{array}$ & $\begin{array}{l}-0.03 \\
(0.02)\end{array}$ \\
\hline $\begin{array}{l}\text { Partner: Usual work hours ( } \geq 35 \\
\text { hours/week) }\end{array}$ & & $\begin{array}{l}0.06^{\star *} \\
(0.02)\end{array}$ & $\begin{array}{l}0.06^{\star *} \\
(0.02)\end{array}$ & & $\begin{array}{l}0.01 \\
(0.02)\end{array}$ & $\begin{array}{l}0.01 \\
(0.02)\end{array}$ \\
\hline Intermediate education & & $\begin{array}{l}0.17+ \\
(0.09)\end{array}$ & $\begin{array}{l}0.17+ \\
(0.09)\end{array}$ & & $\begin{array}{l}0.07 \\
(0.07)\end{array}$ & $\begin{array}{l}0.07 \\
(0.07)\end{array}$ \\
\hline Higher education & & $\begin{array}{c}0.01 \\
(0.09)\end{array}$ & $\begin{array}{c}0.01 \\
(0.09)\end{array}$ & & $\begin{array}{l}0.05 \\
(0.07)\end{array}$ & $\begin{array}{c}0.04 \\
(0.07)\end{array}$ \\
\hline $\begin{array}{l}\text { Usual housework hours ( } \geq 10 \\
\text { hours/week) }\end{array}$ & & $\begin{array}{l}-0.01 \\
(0.01)\end{array}$ & $\begin{array}{l}-0.01 \\
(0.01)\end{array}$ & & $\begin{array}{l}-0.05^{* *} \\
(0.01)\end{array}$ & $\begin{array}{l}-0.05^{* *} \\
(0.01)\end{array}$ \\
\hline In owner-occupancy & & & $\begin{array}{l}0.04 \\
(0.03)\end{array}$ & & & $\begin{array}{l}0.03 \\
(0.03)\end{array}$ \\
\hline Number of rooms & & & $\begin{array}{l}-0.01 \\
(0.00)\end{array}$ & & & $\begin{array}{r}-0.01^{*} \\
(0.01)\end{array}$ \\
\hline Urban area & & & $\begin{array}{c}0.05 \\
(0.03)\end{array}$ & & & $\begin{array}{c}0.07^{*} \\
(0.03)\end{array}$ \\
\hline Intercept & $\begin{array}{c}-0.01 \\
(0.03) \\
\end{array}$ & $\begin{array}{c}-0.28^{\star \star} \\
(0.11)\end{array}$ & $\begin{array}{c}-0.31^{\star *} \\
(0.11)\end{array}$ & $\begin{array}{l}0.19^{\star *} \\
(0.02) \\
\end{array}$ & $\begin{array}{c}0.11 \\
(0.11) \\
\end{array}$ & $\begin{array}{c}0.10 \\
(0.11) \\
\end{array}$ \\
\hline Log-likelihood & -15858.1 & -15766.6 & -15761.9 & -17033.4 & -16956.9 & -16947.1 \\
\hline N Observations & 24731 & 24731 & 24731 & 25554 & 25554 & 25554 \\
\hline $\mathrm{N}$ Individuals & 6220 & 6220 & 6220 & 6415 & 6415 & 6415 \\
\hline
\end{tabular}

Note: Fixed-effects models of the within-subject change gender role attitudes (GRA, z-standardised). Cluster robust standard errors in parentheses. All models control for indicator variables of calendar year. $+p<.1,{ }^{*} p<.05,{ }^{* *} p<.01$.

Data: BHPS (1991-2007, unweighted).

In models 2 and 3, we additionally adjusted for theoretically relevant sets of predictors to test hypotheses about changes in GRA after relocations. In model 2, we added to model 1 variables that capture relevant life course triggers in family and work domains (to address Hypothesis 1: Life course adjustment hypothesis). The inclusion of these variables did not result in major changes in coefficients for couple relocations, which were already insignificant. The coefficient for frequent relocations did not change in size, but it is no longer statistically significant at conventional levels.

Additional results from model 2 reveal that the household division of labour is significantly associated with shifts in GRA. Increases in female labour force participation are associated with egalitarian shifts in GRA among women and men. In particular, female employment leads to a $10 \%$ and $11 \%$ increase in egalitarian GRA for women $(\beta=0.10, p>0.01)$ and for their partners $(\beta=0.11, p>0.01)$, respectively. In addition, female full-time work leads to a $3 \%$ and $6 \%$ increase in egalitarian GRA for women $(\beta=0.03, p>0.05)$ and for their partners $(\beta=0.06, p>0.01)$, respectively. In 
contrast, changes in male labour force participation are not significantly associated with changes in GRA. Housework hours are also related to changes in GRA among women but not among men. Devoting more than 10 hours a week to housework is associated with a $5 \%$ increase in traditional GRA $(\beta=0.05, \mathrm{p}>0.01)$. We note that marital status and children in the household are not significantly associated with shifts in GRA, which is partly due to the fact that we control for key aspects of the household division of labour.

In model 3, we added to model 2 variables that capture housing and residential environments (to address Hypothesis 2: Context adaptation hypothesis). The inclusion of these variables in the model did result in a statistically non-significant coefficient for women's frequent relocations, but the coefficient size decreased only marginally. Despite this, interesting results on moderate changes in GRA among women arise in model 3. First, within-subject changes in some of the newly added variables often require a relocation and are associated with within-subject changes in GRA. Each additional room in a dwelling is associated with a $1 \%$ increase in women's traditional attitudes $(\beta=-0.01, \mathrm{p}<0.05)$. Moving to an urban area is associated with a $7 \%$ increase in women's egalitarian attitudes $(\beta=0.07, \mathrm{p}<0.05)$. Entering owner-occupancy is not associated with changes in GRA for women or men. Overall, results suggest that climbing the housing ladder towards larger dwellings in rural and suburban areas that are often deemed appropriate for family life might induce slightly more traditional GRA among women.

The lack of association between average couple relocations and shifts in GRA according to our results in Table 2 may mask heterogeneity in the associations. To this end, we inspect whether the direction of change in life course and contexts after relocations matters for within-subject changes in GRA. Figure 3 shows gender-specific coefficients of the relocation indicator by the direction of change of selected, relevant variables from fixed-effects models. The direction of the coefficients shown in Figure 3 is mostly expected, with GRA becoming less traditional with relocations to urban areas (except for men), home ownership, smaller housing, and associated increases in work hours and decreases in housework hours. However, results are not statistically significant at conventional levels, and effect sizes are generally moderate (i.e., below $10 \%$ change in GRA). 


\section{Figure 3: Within-subject change in GRA after couple relocations by changes in values of selected variables (Multivariate models)}

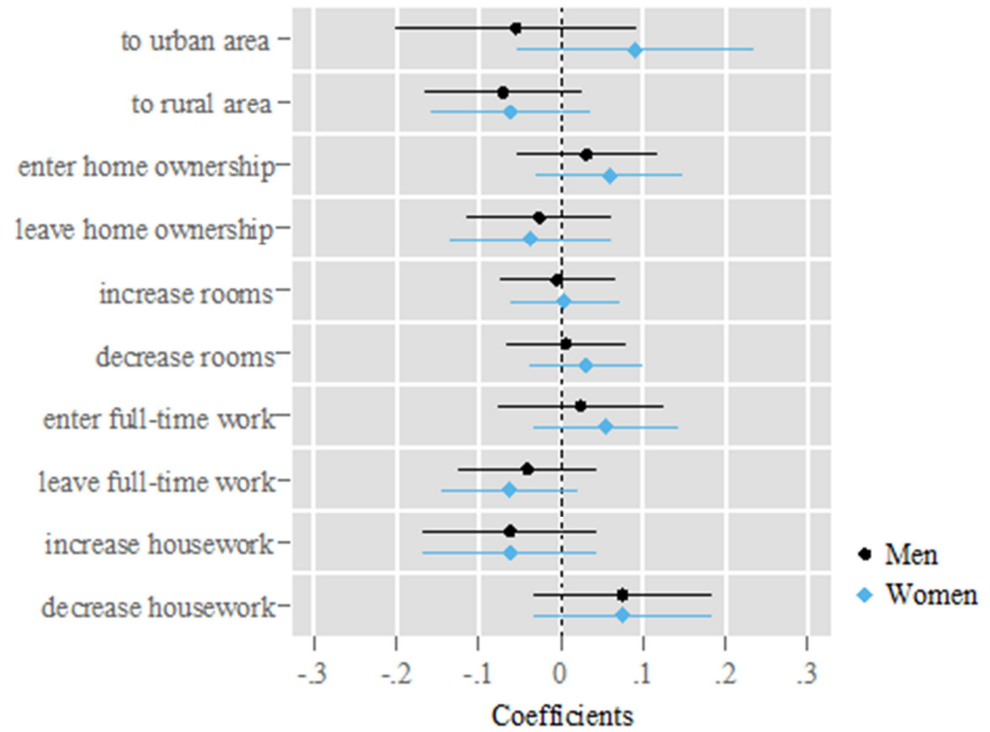

Note: Fixed-effects models of the within-subject change gender role attitudes (GRA, z-standardised). Lines around coefficients are upper and lower $95 \%$ confidence intervals from cluster robust standard errors. Models are run separately by gender and selected sets of variables with values changing after relocations (urban, home ownership, number of rooms, and usual work and housework hours). All models control for variables in Model 1 of Table 2.

Data: BHPS (1991-2007, unweighted).

To test our hypotheses on the heterogeneity in changes in GRA after couple relocations, we estimate fixed-effects models by relocation distance (to address Hypothesis 3) and relocation motives (to address Hypothesis 4 and Hypothesis 5). Figure 4 shows gender-specific model coefficients replicating model 1 in Table 2 but exchanging the overall relocation measure for these factors: two indicators of distancebased relocations (short- and long-distance relocations); four indicators of motive-based relocation types (relocation for job, family, housing and location, and other reasons); and four indicators of relocations by combined job-reasons across partners (relocation for the job of both, for his job, for her job, and for the job of none). Results from Figure 4 show statistically insignificant coefficients for both short- and long-distance relocations. This indicates that any existing heterogeneity in the associations under study might go beyond the traditional divides in the effect of relocation by distance on the gender division of labour. Regarding the indicators of motive-based relocation, 
results from Figure 4 show statistically non-significant coefficients. Hence, any existing heterogeneity in the study associations is not related to specifications of relocations as reasoned by individual respondents. Regarding indicators of relocations by combined job-reasons across partners, results from Figure 4 reveal egalitarian shifts in men's (but not women's) GRA when couple relocations are exclusively for the female partner's job. After relocating for her job, men's egalitarian GRA increase by about $15 \%$. This effect size is relatively large compared to any other relocation coefficient (generally below $10 \%$ and mostly below $5 \%$ ). It is also worth noting that the size and statistical significance of these coefficients remains unchanged after adding covariates capturing life course transitions and changes in the division of household work, as well as the dwelling and location contexts (see Table A-2 in the Appendix).

\section{Figure 4: Within-subject change in GRA after couple relocations by type of relocation (Multivariate models)}

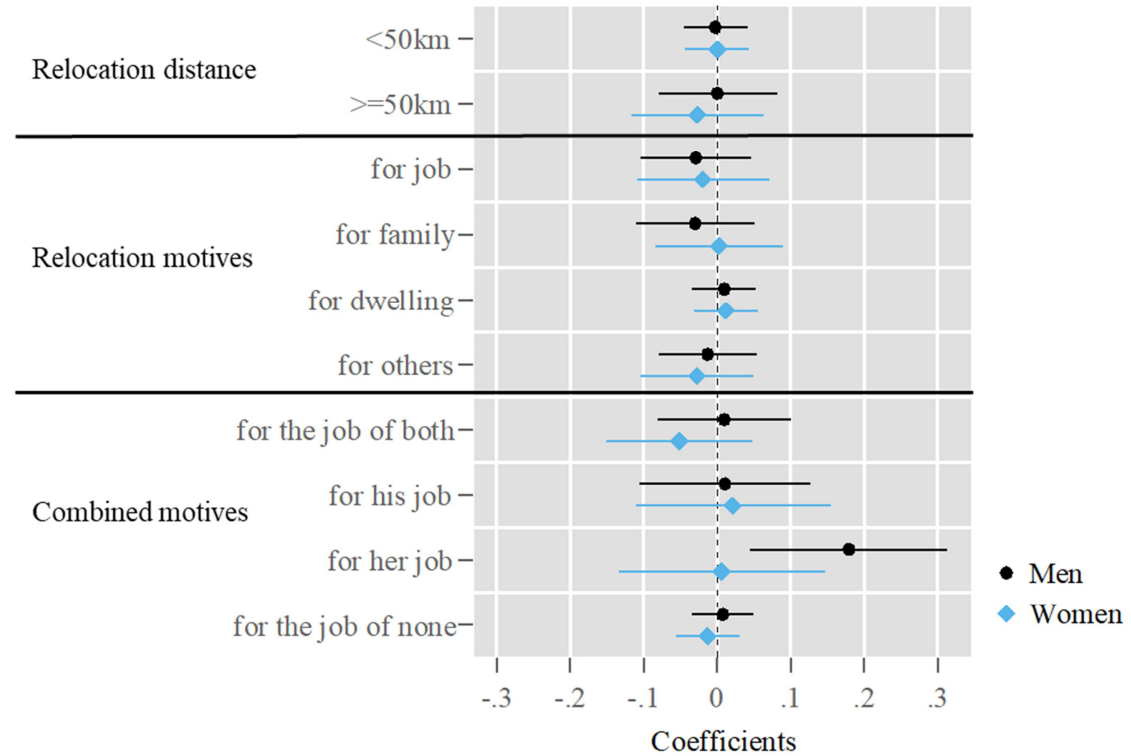

Note: Fixed-effects models of the within-subject change gender role attitudes (GRA, z-standardised). Lines around coefficients are upper and lower 95\% confidence intervals from cluster robust standard errors. Models are run separately by gender and type of relocation (i.e., distance, motives, and combined motives). All models control for variables in Model 1 of Table 2. Data: BHPS (1991-2007, unweighted).

Our results could be biased by feedback effects in the associations. Potentially, feedback effects could render conservative estimates, where changes in GRA after relocations were undermined by the fact that relocations are purposely undertaken only 
when these have little impact for re-evaluation of GRA. To address this, we run a simple sensitivity test to establish temporal order by adding a lagged measure of the relocation indicators as additional model controls in our baseline regression models (Model 1 in Tables 3, 4, 5, and 6). For a consistent comparison across models with and without the lagged relocation indicators, we replicate the original model specifications using the resulting (smaller) analytical sample after lagging relocation indicators. Differences in the significance of coefficients across models with and without the lagged relocation indicators are used as evidence to make preliminary conclusions about the presence of feedback effects based on a different temporal order of the association under study. Overall, results of the sensitivity analysis (presented in Table A-3 for women and Table A-4 for men in the Appendix) provide little evidence for feedback effects. Coefficients for the non-lagged relocation indicators across models with and without lagged indicators are similar. We note that the coefficient for men who relocate for her job remains positive and statistically significant but with a relatively smaller size. In models with lagged relocation indicators for women, the lagged indicators for relocation motivated by other reasons becomes marginally significant (at the non-conventional 90\% level), increasing traditional GRA by about $8 \%$. This hints at the possibility that time-dynamics might be at play, where changes in GRA occur immediately before (or in preparation for) relocations.

\section{Discussion and concluding remarks}

Gender role attitudes are well-known predictors of transitions in individual life courses - including couple relocations - contributing to the generation and accumulation of gender inequalities. While changes in GRA as an outcome of career and family transitions has started to receive some attention, to our knowledge no research has been devoted to the change in GRA after couple relocations. To close this gap in our knowledge, in this study we have examined changes in GRA that follow couple relocations in the British context and have addressed possible explanations for the associations. To this end, we have used linear fixed-effects regression models on a representative sample of partnered women and men from the British Household Panel Survey (BHPS 1991-2007).

One key finding from our analysis is that shifts in individuals' gender ideologies over the life course are rather unaffected by couple relocations. Results from fixedeffects models showed largely insignificant coefficients, for both men and women, of an indicator variable of post-relocation observations. On average, a change in a couple's residence was associated with a shift of less than $5 \%$ of a standardised GRA measure, which was not significant in statistical terms. The insignificant coefficients 
are not due to lack of statistical power since $40 \%$ of our sample respondents relocated together with their partners at least once during the study window. We also used a rather flexible $90 \%$ confidence interval for hypothesis testing given that fixed-effects models are known to produce conservative estimates. In addition, the associations were already small in baseline models without adjusting for potential confounders and mediators of the associations, and we did not find relevant anticipation effects in models that included lagged values of the relocation indicators.

One conclusion of this finding is that the documented changes in GRA after relevant life course transitions, such as marriage, the birth of a child, or changes in employment status, do not appear to extend to couple relocations in the British context (Kan 2007; Berrington et al. 2008; Schober and Scott 2012). Additional model coefficients for associated changes in the division of household labour (in both work and housework hours) were moderately significant in the expected direction, based on prior research, leading to changes of up to 10 percentage points in the standardised GRA measure. While men and women became less traditional with increases in women's employment status and work hours, women became more traditional with increases in housework hours. We did not find significant changes in GRA with marriage and the presence of young children in the household, but our models were already controlling for important mediators of these associations, such as changes in the division of household labour (Berrington et al. 2008). While a specialised literature on the role of couples' relocations (often over long distances) for objective gender inequalities found pre-relocation GRA to be an important predictor (Cooke 2008a; Brandén 2014; Lersch 2016), our results suggest that the average couple relocation does not necessarily affect increasing subjective gender inequality in Britain.

Our second key finding is that only under specific conditions are couple relocations associated with changes in the gender ideologies of partnered individuals. We argued that heterogeneity in the distance and motive of the relocation - which matters for objective gender inequality in Britain - could be relevant for changes in gender relations following a relocation. Our results showed no changes in GRA after short- or long-distance moves, lending no support to our expectation that changes in GRA should be positively associated with the distance of the relocation, given the associated impacts on individuals' daily activities (Hypothesis 3: Relocation distance hypothesis). We also find no shifts in GRA after couple relocations for job-, family- or housing- and location-related motives. Our results did not support our expectation of less gender egalitarian couple arrangements after relocations exclusively for the male partner's job (Hypothesis 4: Male-led mover hypothesis). Stable gender ideologies after long-distance relocations and relocations for the male partner's job contrast with widening gender inequalities in the division of household labour observed after couples' relocations in Britain and in line with the well-established tied-migrant 
hypothesis. On a positive note, even though relocations exclusively for the female partner's job are a minority, our findings show they are associated with men's shifts towards egalitarian attitudes. The results lent partial support to our expectation of decreasing traditional GRA for moves that (in part) support the career of the female partner (Hypothesis 5: Female-led or co-led mover hypothesis). This tentatively suggests that the emerging trends in female-breadwinner households in Britain (Vitali and Mendola 2014) are permeating in couple relocation's behaviour and outcomes.

Regarding the underlying mechanisms, we proposed several explanations for why couple relocations might be conducive to changes in GRA. In the life course adjustment hypothesis (Hypothesis 1), we proposed that life course transitions occurring around the time of relocations are the indirect source of change in GRA after couple relocations. Alternatively, in the context adaptation hypothesis (Hypothesis 2) we proposed that reevaluation of GRA occurs because of exposure to ideas from and adaption of attitudes in the new residential and social contexts. These hypotheses were not supported by our results because the coefficients of changes in GRA after relocations were largely insignificant already before adding covariates for family and career statuses into models. However, some evidence hints at general context-exposure mechanisms channelling shifts to less egalitarian GRA among women but not men. We find that women-specific coefficients for within-subject change in number of rooms in the home and residence in urban areas are statistically significant. That is, women adhere to less egalitarian GRA when moving to larger dwellings and away from urban areas. We tested interactions of these features with the relocation indicator, but associated coefficients were not significant. It is worth noting that we also found that women experienced slight shifts to more traditional attitudes when couples relocated frequently (i.e., more than one time within the study window) in baseline models, but the statistical significance of the association vanished after controlling for housing and location characteristics. This adds to the idea that exposures to certain residential contexts might affect women's GRA. This is an avenue worth exploring further in the British context given the relatively salient regional differences in gender cultures and structures.

We should also highlight some limitations and areas for further improvement. First, we note that our GRA measure reflects agreement or disagreement with rather traditional statements (see Schober and Scott 2012), and thus, analyses using measurements of agreement with egalitarian GRA are needed to further address whether couple relocations affect changes in egalitarian GRA. Recent contributions to the literature on GRA suggest that we should consider the coexistence of different forms of egalitarian gender ideology due to the emergence of two main forms in contemporary Britain that deserve further scrutiny (Knight and Brinton 2017). Second, the re-evaluation of the individual's own attitudes can be a long-term process as individuals need time to get to know the new context and adapt their practices. Thus, 
changes in GRA may not occur immediately after couple relocations but might instead stretch over time or be transitory and impermanent. That is, complex time-dynamics may potentially mask significant associations. Third, the use of pre-coded categories of relocation motivations is problematic, such as those offered in BHPS and other major household panel surveys, since these often pool people's specific motives into nebulous categories (Coulter and Scott 2015) and, thus, may obscure exactly why people relocate. In addition, by addressing post-relocation motives, we overlooked the motives of individuals who do not complete a relocation. Given increases in the numbers of tied-stayers (i.e., individuals who would like to relocate but decide to stay because of their partners), addressing how unfulfilled relocation intentions affect their attitudes and further subjective and objective outcomes is not trivial.

Despite these limitations, our study contributes to the literature by addressing, for the first time, gender role attitudes as an outcome of couple relocations. This adds to the incipient study of the potential impacts of couple relocations on subjective outcomes, which could be extended to other measures such as subjective well-being, relationship quality and satisfaction, or child well-being. Beyond expanding the knowledge on sources of gender asymmetry that follow couple relocations, our results also contribute to a better understanding of the life course dynamics of GRA.

\section{Acknowledgements}

We would like to thank participants at the Spatial Mobility, Families and Gender Inequality in the Labour Market symposium (Bremen, 28-29 March 2017), Gundula Zoch, and two anonymous reviewers for thoughtful comments and suggestions. This research was partly supported by the German Research Foundation - DFG (Grant number: VI711/1-1) and the Ministerio de Economía y Competitividad de España (Grant number: RYC-2015-18254). Data from the British Household Panel Survey (BHPS) is available from the UK Data Archive (http://www.data-archive.ac.uk). The findings and views reported in this article are those of the authors. 


\section{References}

Ajzen, I. (2005). Attitudes, personality, and behavior. Maidenhead: Open University Press.

Bailey, A.J. (2009). Population geography: Lifecourse matters. Progress in Human Geography 33(3): 407-418. doi:10.1177/0309132508096355.

Bailey, A.J. and Boyle, P.J. (2004). Untying and retying family migration in the New Europe. Journal of Ethnic and Migration Studies 30(2): 229-241. doi:10.1080/ 1369183042000200678.

Barrett, E.J. (2013). Women's work attitudes, aspirations, and workforce participation before and after relocation from public housing. Journal of Sociology and Social Welfare 40(3): 135-161.

Baxter, J., Buchler, S., Perales, F., and Western, M. (2014). A life-changing event: First births and men's and women's attitudes to mothering and gender divisions of labor. Social Forces 93(3): 989-1014. doi:10.1093/sf/sou103.

Berrington, A., Hu, Y., Smith, P.W., and Sturgis, P. (2008). A graphical chain model for reciprocal relationships between women's gender role attitudes and labour force participation. Journal of the Royal Statistical Society Series A: Statistics in Society 171(1): 89-108. doi:10.1111/j.1467-985X.2007.00510.x.

Bolzendahl, C.I. and Myers, D.J. (2004). Feminist attitudes and support for gender equality: Opinion change in women and men, 1974-1998. Social Forces 83(2): 759-789. doi:10.1353/sof.2005.0005.

Boterman, W.R. and Bridge, G. (2015). Gender, class and space in the field of parenthood: comparing middle-class fractions in Amsterdam and London. Transactions of the Institute of British Geographers 40(2): 249-261. doi:10.1111/tran.12073.

Boyle, P., Cooke, T.J., Halfacree, K., and Smith, D. (2001). A cross-national comparison of the impact of family migration on women's employment status. Demography 38(2): 201-213.

Boyle, P.J., Cooke, T., Halfacree, K., and Smith, D. (2003). The effect of long-distance family migration and motherhood on partnered women's labour-market activity rates in Great Britain and the USA. Environment and Planning A: Economy and Space 35(12): 2097-2114. doi:10.1068/a35138. 
Boyle, P.J., Feng, Z., and Gayle, V. (2009). A new look at family migration and women's employment status. Journal of Marriage and Family 71(2): 417-431. doi:10.1111/j.1741-3737.2009.00608.x.

Brandén, M. (2014). Gender, gender ideology, and couples' migration decisions. Journal of Family Issues 35(7): 950-971. doi:10.1177/0192513X14522244.

Braun, M. and Scott, J. (2009). Changing public views of gender roles in seven nations, 1988-2002. In: Haller, M., Jowell, R., and Smith, T.W. (eds.). The International Social Survey Programme 1984-2009: Charting the globe. Oxford: Routledge: 358-377.

Champion, T., Coombes, M.G., Raybould, S.R., and Wymer, C. (2007). Migration and socio-economic change: A 2001 census analysis of Britain's larger cities. Bristol: Policy Press.

Christie-Mizell, C.A., Keil, J.M., Kimura, A., and Blount, S.A. (2007). Gender ideology and motherhood: The consequences of race on earnings. Sex Roles 57(9-10): 689-702. doi:10.1007/s11199-007-9292-3.

Clark, W.A.V. and Davis Withers, S. (2009). Fertility, mobility and labour-force participation: A study of synchronicity. Population, Space and Place 15(4): 305-321. doi:10.1002/psp.555.

Clark, W.A.V. and Huang, Y. (2003). The life course and residential mobility in British housing markets. Environment and Planning A: Economy and Space 35(2): 323339. doi:10.1068/a3542.

Clark, W.A.V. and Huang, Y. (2006). Balancing move and work: Women's labour market exits and entries after family migration. Population, Space and Place 12(1): 31-44. doi:10.1002/psp.388.

Cooke, L.P. (2011). Gender-class equality in political economies. New York: Routledge.

Cooke, L.P. (2014). Gendered parenthood penalties and premiums across the earnings distribution in Australia, the United Kingdom, and the United States. European Sociological Review 30(3): 360-372. doi:10.1093/esr/jcu044.

Cooke, T.J. (2001). 'Trailing wife' or 'trailing mother'? The effect of parental status on the relationship between family migration and the labor-market participation of married women. Environment and Planning A: Economy and Space 33(3): 419430. doi:10.1068/a33140. 
Cooke, T.J. (2003). Family migration and the relative earnings of husbands and wives. Annals of the Association of American Geographers 93(2): 338-349. doi:10.1111/1467-8306.9302005.

Cooke, T.J. (2008a). Gender role beliefs and family migration. Population, Space and Place 14(3): 163-175. doi:10.1002/psp.485.

Cooke, T.J. (2008b). Migration in a family way. Population, Space and Place 14(4): 255-265. doi:10.1002/psp.500.

Cooke, T.J. and Bailey, A.J. (1999). The effect of migration, migration history, and self-selection on married women's labour market achievement. In: Boyle, P.J. and Halfacree, K.H. (eds.). Migration and gender in the developed world. London: Routledge: 102-128.

Cooke, T.J., Boyle, P.J., Couch, K., and Feijten, P. (2009). A longitudinal analysis of family migration and the gender gap in earnings in the United States and Great Britain. Demography 46(1): 147-167. doi:10.1353/dem.0.0036.

Corrigall, E.A. and Konrad, A.M. (2007). Gender role attitudes and careers: A longitudinal study. Sex Roles 56(11-12): 847-855. doi:10.1007/s11199-0079242-0.

Cotter, D., Hermsen, J.M., and Vanneman, R. (2011). The end of the gender revolution? Gender role attitudes from 1977 to 2008. American Journal of Sociology 117(1): 259-289. doi:10.1086/658853.

Coulter, R. and Scott, J. (2015). What motivates residential mobility? Re-examining self-reported reasons for desiring and making residential moves. Population, Space and Place 21(4): 354-371. doi:10.1002/psp.1863.

Cousins, C.R. and Tang, N. (2004). Working time and work and family conflict in the Netherlands, Sweden and the UK. Work, Employment and Society 18(3): 531549. doi:10.1177/0950017004045549.

Cunningham, M. (2005). Gender in cohabitation and marriage: The influence of gender ideology on housework allocation over the life course. Journal of Family Issues 26(8): 1037-1061. doi:10.1177/0192513X04273592.

Danigelis, N.L., Hardy, M., and Cutler, S.J. (2007). Population aging, intracohort aging, and sociopolitical attitudes. American Sociological Review 72(5): 812-830. doi:10.1177/000312240707200508. 
Davis, S.N. and Greenstein, T.N. (2009). Gender ideology: Components, predictors, and consequences. Annual Review of Sociology 35: 87-105. doi:10.1146/ annurev-soc-070308-115920.

Dex, S., Ward, K., and Joshi, H. (2008). Changes in women's occupations and occupational mobility over 25 years. In: Scott, J., Dex, S., and Joshi, H. (eds.). Women and employment: Changing lives and new challenges. Cheltenham: Edgar Elgar: 54-80. doi:10.4337/9781848442931.00009.

Duncan, S. and Smith, D. (2002). Geographies of family formations: Spatial differences and gender cultures in Britain. Transactions of the Institute of British Geographers 27(4): 471-493. doi:10.1111/1475-5661.00066.

England, P. (2010). The gender revolution: Uneven and stalled. Gender and Society 24(2): 149-166. doi:10.1177/0891243210361475.

Esping-Andersen, G. (1990). The three worlds of welfare capitalism. Princeton: Princeton University Press.

Fan, P.L. and Marini, M.M. (2000). Influences on gender-role attitudes during the transition to adulthood. Social Science Research 29(2): 258-283. doi:10.1006/ ssre.1999.0669.

Halfacree, K.H. (1995). Household migration and the structuration of patriarchy: evidence from the USA. Progress in Human Geography 19(2): 159-182. doi:10.1177/030913259501900201.

Huinink, J., Vidal, S., and Kley, S. (2014). Individuals' openness to migrate and job mobility. Social Science Research 44: 1-14. doi:10.1016/j.ssresearch.2013. 10.006 .

Jarallah, Y., Perales, F., and Baxter, J. (2016). Parenthood and men's and women's gender-role attitudes: Does child's gender matter? Queensland: Lifecourse Center (Working Paper 2016-12).

Kan, M.Y. (2007). Work orientation and wives' employment careers: an evaluation of Hakim's preference theory. Work and Occupations 34(4): 430-462. doi: $10.1177 / 0730888407307200$.

Kley, S. and Drobnič, S. (2019). Does moving for family nest-building inhibit mothers' labour force (re-)entry? Demographic Research 40(7): 155-184. doi:10.4054/ DemRes.2019.40.7. 
Knight, C.R. and Brinton, M.C. (2017). One egalitarianism or several? Two decades of gender-role attitude change in Europe. American Journal of Sociology 122(5): 1485-1532. doi:10.1086/689814.

Krosnick, J.A. and Alwin, D.F. (1989). Aging and susceptibility to attitude change. Journal of Personality and Social Psychology 57(3): 416-425. doi:10.1037/ 0022-3514.57.3.416.

Lersch, P.M. (2016). Family migration and subsequent employment: The effect of gender ideology. Journal of Marriage and Family 78(1): 230-245. doi:10.1111/ jomf.12251.

Lersch, P.M. and Dewilde, C. (2015). Employment insecurity and first-time homeownership: Evidence from twenty-two European countries. Environment and Planning A: Economy and Space 47(3): 607-624. doi:10.1068/a130358p.

MacDonald, H. (1999). Women's employment and commuting: Explaining the links. Journal of Planning Literature 13(3): 267-283. doi:10.1177/ 08854129922092397.

Mincer, J. (1978). Family migration decisions. Journal of Political Economy 86(5): 749-773. doi:10.1086/260710.

Morrison, P.S. and Clark, W.A.V. (2011). Internal migration and employment: Macro flows and micro motives. Environment and Planning A: Economy and Space 43(8): 1948-1964. doi:10.1068/a43531.

Mulder, C.H. (2006). Home-ownership and family formation. Journal of Housing and the Built Environment 21(3): 281-298. doi:10.1007/s10901-006-9050-9.

Mulder, C.H. (2018). Putting family centre stage: Ties to non-resident family, internal migration and immobility. Demographic Research 39(43): doi:10.4054/ DemRes.2018.39.43.

Mulder, C.H. and Billari, F.C. (2010). Homeownership regimes and low fertility. Housing Studies 25(4): 527-541. doi:10.1080/02673031003711469.

Mulder, C.H. and Hooimeijer, P. (1999). Residential relocations in the life course. In: van Wissen, L.J.G. and Dykstra, P.A. (eds.). Population issues. Dordrecht: Springer: 159-186. doi:10.1007/978-94-011-4389-9_6.

Nieuwenhuis, J., Tammaru, T., van Ham, M., Hedman, L., and Manley, D. (2017). Does segregation reduce socio-spatial mobility? Evidence from four European countries with different inequality and segregation contexts. Bonn: Institute of Labor Economics (IZA Discussion Paper 11123) 
Nightingale, G., McCollum, D., and Ernsten, A. (2017). Who moves up the social ladder in the UK? Southampton: University of Southampton (ESRC Centre for Population Change Briefing Paper Series 39).

Perales, F. and Vidal, S. (2013). Occupational characteristics, occupational sex segregation, and family migration decisions. Population, Space and Place 19(5): 487-504. doi:10.1002/psp.1727.

Perales, F., Lersch, P.M., and Baxter, J. (2017). Birth cohort, ageing and gender ideology: Lessons from British panel data. Queensland: Lifecourse Center (Working Paper 2017-01).

Schober, P. and Scott, J. (2012). Maternal employment and gender role attitudes: Dissonance among British men and women in the transition to parenthood. Work, Employment and Society 26(3): 514-530. doi:10.1177/ 0950017012438577.

Scott, J., Alwin, D.F., and Braun, M. (1996). Generational changes in gender-role attitudes: Britain in a cross-national perspective. Sociology 30(3): 471-492. doi:10.1177/0038038596030003004.

Shihadeh, E.S. (1991). The prevalence of husband-centered migration: employment consequences for married mothers. Journal of Marriage and the Family 53(2): 432-444. doi:10.2307/352910.

Smith, D.P. (2011). Geographies of long-distance family migration: moving to a 'spatial turn'. Progress in Human Geography 35(5): 652-668. doi:10.1177/ 0309132510394011.

Sullivan, O. and Gershuny, J. (2016). Change in spousal human capital and housework: A longitudinal analysis. European Sociological Review 32(6): 864-880. doi:10.1093/esr/jcw043.

Taylor, M.F., Brice, J., Buck, N.H., and Prentice-Lane, E. (2010). British household panel survey: User manual: Volume A. Colchester: ISER.

Taylor, M.P. (2007). Tied migration and subsequent employment: Evidence from couples in Britain. Oxford Bulletin of Economics and Statistics 69(6): 795-818. doi:10.1111/j.1468-0084.2007.00482.x.

Thévenon, O. (2011). Family policies in OECD countries: A comparative analysis. Population and Development Review 37(1): 57-87. doi:10.1111/j.1728-4457. 2011.00390.x. 
van Gameren, E. (2013). The role of economic incentives and attitudes in participation and childcare decisions. Journal of Family and Economic Issues 34(3): 296-313. doi:10.1007/s10834-012-9332-1.

Verberg, N. (2000). Homeownership and politics: Testing the political incorporation thesis. Canadian Journal of Sociology 25(2): 169-195. doi:10.2307/3341822.

Vidal, S., Huinink, J., and Feldhaus, M. (2017). Fertility intentions and residential relocations. Demography 54(4): 1305-1330. doi:10.1007/s13524-017-0592-0.

Vidal, S., Perales, F., and Baxter, J. (2016). Dynamics of domestic labor across shortand long-distance family relocations. Journal of Marriage and Family 78(2): 364-382. doi:10.1111/jomf.12269.

Vidal, S., Perales, F., Lersch, P.M., and Brandén, M. (2017). Family migration in a cross-national perspective: The importance of within-couple employment arrangements in Australia, Britain, Germany, and Sweden. Demographic Research 36(10): 307-338. doi:10.4054/DemRes.2017.36.10.

Vitali, A. and Mendola, D. (2014). Women as main earners in Europe. Southampton: Centre for Population Change (Working Paper 56). doi:10.2139/ssrn.2555172.

Walks, R.A. (2004). Suburbanization, the vote, and changes in federal and provincial political representation and influence between inner cities and suburbs in large Canadian urban regions, 1945-1999. Urban Affairs Review 39(4): 411-440. doi: $10.1177 / 1078087403260787$.

West, C. and Zimmerman, D.H. (1987). Doing gender. Gender \& Society 1(2): 125151.

Zoch, G. (2018). Expanding public childcare services for under-threes: An empirical investigation of maternal employment and gender ideologies in East and West Germany [PhD thesis]. Bamberg: Otto-Friedrich-Universität Bamberg. 
Vidal \& Lersch: Changes in gender role attitudes following couples’ residential relocations

\section{Appendix}

\section{Table A-1: Summary statistics of model covariates}

\begin{tabular}{lcccccccc}
\hline & \multicolumn{2}{c}{ Men } & \multicolumn{2}{c}{ Women } & \multicolumn{3}{c}{ Overall } \\
& Mean & St. Dev. & Mean & St. Dev. & Mean & St. Dev. & Min. & Max. \\
\hline Frequent relocations & 0.14 & 0.35 & 0.14 & 0.35 & 0.14 & 0.35 & 0 & 1 \\
Two+ years since relocation & 0.28 & 0.45 & 0.28 & 0.45 & 0.28 & 0.45 & 0 & 1 \\
Age 18-29 & 0.12 & 0.32 & 0.16 & 0.36 & 0.14 & 0.34 & 0 & 1 \\
Age 30-39 & 0.24 & 0.43 & 0.25 & 0.43 & 0.24 & 0.43 & 0 & 1 \\
Age 40-49 & 0.22 & 0.42 & 0.22 & 0.41 & 0.22 & 0.42 & 0 & 1 \\
Age 50-64 & 0.43 & 0.49 & 0.38 & 0.49 & 0.40 & 0.49 & 0 & 1 \\
Married & 0.83 & 0.38 & 0.83 & 0.38 & 0.83 & 0.38 & 0 & 1 \\
No children in the household & 0.48 & 0.50 & 0.48 & 0.50 & 0.48 & 0.50 & 0 & 1 \\
Children under 5 & 0.46 & 0.50 & 0.46 & 0.50 & 0.46 & 0.50 & 0 & 1 \\
Children 5-17 & 0.06 & 0.24 & 0.06 & 0.24 & 0.06 & 0.24 & 0 & 1 \\
Household (log-) income & 9.69 & 0.67 & 9.68 & 0.67 & 9.69 & 0.67 & 0 & 13.72 \\
Employed & 0.72 & 0.45 & 0.60 & 0.49 & 0.66 & 0.48 & 0 & 1 \\
Weekly work hours $(\geq 35)$ & 0.66 & 0.48 & 0.28 & 0.45 & 0.47 & 0.50 & 0 & 1 \\
Partner: Employed & 0.62 & 0.49 & 0.71 & 0.45 & 0.67 & 0.47 & 0 & 1 \\
Partner: Work hours $(\geq 35)$ & 0.29 & 0.46 & 0.65 & 0.48 & 0.47 & 0.50 & 0 & 1 \\
Lower education & 0.34 & 0.47 & 0.35 & 0.48 & 0.35 & 0.48 & 0 & 1 \\
Intermediate education & 0.30 & 0.46 & 0.32 & 0.47 & 0.31 & 0.46 & 0
\end{tabular}

Data: BHPS (1991-2007, unweighted). 
Table A-2: Within-subject change in GRA after couple relocations by type of relocation (Multivariate models)

\begin{tabular}{|c|c|c|c|c|c|c|}
\hline & \multicolumn{3}{|c|}{ Men } & \multicolumn{3}{|c|}{ Women } \\
\hline & $\begin{array}{c}\text { Model } 1 \\
\text { B/(SE) }\end{array}$ & $\begin{array}{c}\text { Model } 2 \\
\text { B/(SE) }\end{array}$ & $\begin{array}{c}\text { Model } 3 \\
\text { B/(SE) }\end{array}$ & $\begin{array}{c}\text { Model } 1 \\
\text { B/(SE) }\end{array}$ & $\begin{array}{c}\text { Model } 2 \\
\text { B/(SE) }\end{array}$ & $\begin{array}{c}\text { Model } 3 \\
\text { B/(SE) }\end{array}$ \\
\hline \multicolumn{7}{|l|}{ Relocation distance } \\
\hline Short distance & $\begin{array}{l}-0.00 \\
(0.02)\end{array}$ & $\begin{array}{c}0.00 \\
(0.02)\end{array}$ & $\begin{array}{c}0.00 \\
(0.02)\end{array}$ & $\begin{array}{c}0.01 \\
(0.02)\end{array}$ & $\begin{array}{c}0.01 \\
(0.02)\end{array}$ & $\begin{array}{c}0.01 \\
(0.02)\end{array}$ \\
\hline Long distance & $\begin{array}{c}0.00 \\
(0.04)\end{array}$ & $\begin{array}{c}0.00 \\
(0.04)\end{array}$ & $\begin{array}{c}0.02 \\
(0.04)\end{array}$ & $\begin{array}{l}-0.03 \\
(0.05)\end{array}$ & $\begin{array}{l}-0.03 \\
(0.05)\end{array}$ & $\begin{array}{l}-0.01 \\
(0.05)\end{array}$ \\
\hline \multicolumn{7}{|l|}{ Individual motives } \\
\hline for job & $\begin{array}{l}-0.03 \\
(0.04)\end{array}$ & $\begin{array}{c}-0.03 \\
(0.04)\end{array}$ & $\begin{array}{c}-0.02 \\
(0.04)\end{array}$ & $\begin{array}{c}-0.02 \\
(0.05)\end{array}$ & $\begin{array}{c}-0.02 \\
(0.05)\end{array}$ & $\begin{array}{l}-0.01 \\
(0.05)\end{array}$ \\
\hline for family & $\begin{array}{c}-0.03 \\
(0.04)\end{array}$ & $\begin{array}{c}-0.03 \\
(0.04)\end{array}$ & $\begin{array}{c}-0.03 \\
(0.04)\end{array}$ & $\begin{array}{c}0.00 \\
(0.04)\end{array}$ & $\begin{array}{c}-0.01 \\
(0.04)\end{array}$ & $\begin{array}{c}-0.00 \\
(0.04)\end{array}$ \\
\hline for housing/area & $\begin{array}{c}0.01 \\
(0.02)\end{array}$ & $\begin{array}{c}0.01 \\
(0.02)\end{array}$ & $\begin{array}{c}0.01 \\
(0.02)\end{array}$ & $\begin{array}{c}0.01 \\
(0.02)\end{array}$ & $\begin{array}{c}0.01 \\
(0.02)\end{array}$ & $\begin{array}{c}0.02 \\
(0.02)\end{array}$ \\
\hline for other motives & $\begin{array}{c}-0.01 \\
(0.03)\end{array}$ & $\begin{array}{c}-0.01 \\
(0.03)\end{array}$ & $\begin{array}{c}-0.00 \\
(0.03)\end{array}$ & $\begin{array}{c}-0.03 \\
(0.04)\end{array}$ & $\begin{array}{l}-0.02 \\
(0.04)\end{array}$ & $\begin{array}{c}-0.02 \\
(0.04)\end{array}$ \\
\hline \multicolumn{7}{|l|}{ Combined job motives } \\
\hline for the job of both & $\begin{array}{c}0.01 \\
(0.05)\end{array}$ & $\begin{array}{c}0.01 \\
(0.05)\end{array}$ & $\begin{array}{c}0.02 \\
(0.05)\end{array}$ & $\begin{array}{l}-0.05 \\
(0.05)\end{array}$ & $\begin{array}{c}-0.06 \\
(0.05)\end{array}$ & $\begin{array}{l}-0.04 \\
(0.05)\end{array}$ \\
\hline for his job & $\begin{array}{c}0.01 \\
(0.06)\end{array}$ & $\begin{array}{c}0.02 \\
(0.06)\end{array}$ & $\begin{array}{c}0.02 \\
(0.06)\end{array}$ & $\begin{array}{c}0.02 \\
(0.07)\end{array}$ & $\begin{array}{c}0.02 \\
(0.07)\end{array}$ & $\begin{array}{c}0.03 \\
(0.07)\end{array}$ \\
\hline for her job & $\begin{array}{l}0.18^{\star *} \\
(0.07)\end{array}$ & $\begin{array}{l}0.15^{\star} \\
(0.07)\end{array}$ & $\begin{array}{c}0.16^{*} \\
(0.07)\end{array}$ & $\begin{array}{c}0.01 \\
(0.07)\end{array}$ & $\begin{array}{l}-0.00 \\
(0.07)\end{array}$ & $\begin{array}{c}0.00 \\
(0.07)\end{array}$ \\
\hline for the job of none & $\begin{array}{c}0.01 \\
(0.02) \\
\end{array}$ & $\begin{array}{c}0.01 \\
(0.02) \\
\end{array}$ & $\begin{array}{c}0.01 \\
(0.02) \\
\end{array}$ & $\begin{array}{c}-0.01 \\
(0.02) \\
\end{array}$ & $\begin{array}{c}-0.01 \\
(0.02) \\
\end{array}$ & $\begin{array}{c}-0.01 \\
(0.02) \\
\end{array}$ \\
\hline N Observations & 24731 & 24731 & 24731 & 25554 & 25554 & 25554 \\
\hline $\mathrm{N}$ Individuals & 6220 & 6220 & 6220 & 6415 & 6415 & 6415 \\
\hline
\end{tabular}

Note: Fixed-effects models of the within-subject change gender role attitudes (GRA, z-standardised). Cluster robust standard errors in parentheses. Models are run separately by gender and type of relocation (i.e., distance, motives, and combined motives). All models control for indicator variables of calendar year. Additional control variables in models as in Table 2.

Data: BHPS (1991-2007, unweighted). 
Vidal \& Lersch: Changes in gender role attitudes following couples' residential relocations

Table A-3: Fixed-effects models of gender ideology (Women)

\begin{tabular}{|c|c|c|c|c|c|c|c|c|}
\hline & $\begin{array}{l}\text { Model } 1 \\
\text { B/(SE) }\end{array}$ & $\begin{array}{l}\text { Model } 1 \\
\text { w/lag } \\
\text { B/(SE) }\end{array}$ & $\begin{array}{l}\text { Model } 1 \\
\text { B/(SE) }\end{array}$ & $\begin{array}{l}\text { Model } 1 \\
\text { w/lag } \\
\text { B/(SE) }\end{array}$ & $\begin{array}{l}\text { Model } 1 \\
\text { B/(SE) }\end{array}$ & $\begin{array}{l}\text { Model } 1 \\
\text { w/lag } \\
\text { B/(SE) }\end{array}$ & $\begin{array}{l}\text { Model } 1 \\
\text { B/(SE) }\end{array}$ & $\begin{array}{l}\text { Model 1 } \\
\text { w/lag } \\
\text { B/(SE) }\end{array}$ \\
\hline Relocation & $\begin{array}{c}0.03 \\
(0.03)\end{array}$ & $\begin{array}{c}0.03 \\
(0.03)\end{array}$ & & & & & & \\
\hline Relocation (lag) & & $\begin{array}{c}0.03 \\
(0.03)\end{array}$ & & & & & & \\
\hline $\begin{array}{l}\text { Relocation over short } \\
\text { distance }\end{array}$ & & & $\begin{array}{c}0.02 \\
(0.03)\end{array}$ & $\begin{array}{c}0.02 \\
(0.03)\end{array}$ & & & & \\
\hline $\begin{array}{l}\text { Relocation over long } \\
\text { distance }\end{array}$ & & & $\begin{array}{l}-0.01 \\
(0.05)\end{array}$ & $\begin{array}{c}0.01 \\
(0.06)\end{array}$ & & & & \\
\hline $\begin{array}{l}\text { Relocation over short } \\
\text { distance (lag) }\end{array}$ & & & & $\begin{array}{c}0.01 \\
(0.03)\end{array}$ & & & & \\
\hline $\begin{array}{l}\text { Relocation over long } \\
\text { distance (lag) }\end{array}$ & & & & $\begin{array}{l}-0.04 \\
(0.05)\end{array}$ & & & & \\
\hline Relocation for job & & & & & $\begin{array}{l}-0.05 \\
(0.06)\end{array}$ & $\begin{array}{l}-0.02 \\
(0.05)\end{array}$ & & \\
\hline Relocation for family & & & & & $\begin{array}{c}0.03 \\
(0.06)\end{array}$ & $\begin{array}{c}0.04 \\
(0.06)\end{array}$ & & \\
\hline $\begin{array}{l}\text { Relocation for } \\
\text { housing/area }\end{array}$ & & & & & $\begin{array}{c}0.03 \\
(0.03)\end{array}$ & $\begin{array}{c}0.02 \\
(0.03)\end{array}$ & & \\
\hline $\begin{array}{l}\text { Relocation for other } \\
\text { motives }\end{array}$ & & & & & $\begin{array}{c}0.03 \\
(0.04)\end{array}$ & $\begin{array}{c}0.07 \\
(0.05)\end{array}$ & & \\
\hline Relocation for job (lag) & & & & & & $\begin{array}{l}-0.06 \\
(0.05)\end{array}$ & & \\
\hline $\begin{array}{l}\text { Relocation for family } \\
\text { (lag) }\end{array}$ & & & & & & $\begin{array}{c}-0.02 \\
(0.05)\end{array}$ & & \\
\hline $\begin{array}{l}\text { Relocation for } \\
\text { housing/area (lag) }\end{array}$ & & & & & & $\begin{array}{l}0.00 \\
(0.02)\end{array}$ & & \\
\hline $\begin{array}{l}\text { Relocation for other } \\
\text { motives (lag) }\end{array}$ & & & & & & $\begin{array}{l}-0.08+ \\
(0.05)\end{array}$ & & \\
\hline $\begin{array}{l}\text { Relocation for the job of } \\
\text { both }\end{array}$ & & & & & & & $\begin{array}{l}-0.06 \\
(0.06)\end{array}$ & $\begin{array}{c}-0.03 \\
(0.06)\end{array}$ \\
\hline Relocation for his job & & & & & & & $\begin{array}{c}0.02 \\
(0.08)\end{array}$ & $\begin{array}{c}0.04 \\
(0.08)\end{array}$ \\
\hline Relocation for her job & & & & & & & $\begin{array}{c}0.10 \\
(0.09)\end{array}$ & $\begin{array}{c}0.10 \\
(0.10)\end{array}$ \\
\hline $\begin{array}{l}\text { Relocation for the job of } \\
\text { none }\end{array}$ & & & & & & & $\begin{array}{c}0.01 \\
(0.03)\end{array}$ & $\begin{array}{c}-0.00 \\
(0.03)\end{array}$ \\
\hline $\begin{array}{l}\text { Relocation for the job of } \\
\text { both (lag) }\end{array}$ & & & & & & & & $\begin{array}{l}-0.05 \\
(0.05)\end{array}$ \\
\hline $\begin{array}{l}\text { Relocation for his job } \\
\text { (lag) }\end{array}$ & & & & & & & & $\begin{array}{c}-0.02 \\
(0.08)\end{array}$ \\
\hline $\begin{array}{l}\text { Relocation for her job } \\
\text { (lag) }\end{array}$ & & & & & & & & $\begin{array}{l}0.01 \\
(0.10)\end{array}$ \\
\hline $\begin{array}{l}\text { Relocation for the job of } \\
\text { none (lag) }\end{array}$ & & & & & & & & $\begin{array}{c}0.04 \\
(0.03)\end{array}$ \\
\hline Repeated relocations & $\begin{array}{c}-0.05+ \\
(0.03) \\
\end{array}$ & $\begin{array}{c}-0.06+ \\
(0.03) \\
\end{array}$ & $\begin{array}{l}-0.05 \\
(0.03) \\
\end{array}$ & $\begin{array}{c}-0.05 \\
(0.03) \\
\end{array}$ & $\begin{array}{c}-0.06+ \\
(0.03) \\
\end{array}$ & $\begin{array}{c}-0.05 \\
(0.04) \\
\end{array}$ & $\begin{array}{l}-0.05 \\
(0.03) \\
\end{array}$ & $\begin{array}{c}-0.05 \\
(0.03) \\
\end{array}$ \\
\hline$\overline{\mathrm{LL}}$ & -11714.17 & -11713.15 & -11702.06 & -11701.51 & -11706.57 & -11702.46 & -11713.25 & -11709.89 \\
\hline N Observations & 19139 & 19139 & 19127 & 19127 & 19138 & 19138 & 19139 & 19139 \\
\hline $\mathrm{N}$ Individuals & 5057 & 5057 & 5055 & 5055 & 5057 & 5057 & 5057 & 5057 \\
\hline
\end{tabular}

Note: Outcome variable is egalitarian gender ideology (z-standardised), cluster robust standard errors in parentheses. Additional control variables in models as in Model 1 of Table $2 .+p<.1,{ }^{*} p<.05,{ }^{*} p<.01$.

Data: BHPS (1991-2007, unweighted). 
Table A-4: Fixed-effects models of gender ideology (Men)

\begin{tabular}{|c|c|c|c|c|c|c|c|c|}
\hline & $\begin{array}{l}\text { Model } 1 \\
\text { B/(SE) }\end{array}$ & $\begin{array}{l}\text { Model } 1 \\
\text { w/lag } \\
\text { B/(SE) }\end{array}$ & $\begin{array}{l}\text { Model } 1 \\
\text { B/(SE) }\end{array}$ & $\begin{array}{l}\text { Model } 1 \\
\text { w/lag } \\
\text { B/(SE) }\end{array}$ & $\begin{array}{l}\text { Model } 1 \\
\text { B/(SE) }\end{array}$ & $\begin{array}{l}\text { Model } 1 \\
\text { w/lag } \\
\text { B/(SE) }\end{array}$ & $\begin{array}{l}\text { Model } 1 \\
\text { B/(SE) }\end{array}$ & $\begin{array}{l}\text { Model 1 } \\
\text { w/lag } \\
\text { B/(SE) }\end{array}$ \\
\hline Relocation & $\begin{array}{l}-0.02 \\
(0.03)\end{array}$ & $\begin{array}{c}-0.02 \\
(0.03)\end{array}$ & & & & & & \\
\hline Relocation (lag) & & $\begin{array}{c}0.01 \\
(0.02)\end{array}$ & & & & & & \\
\hline $\begin{array}{l}\text { Relocation over short } \\
\text { distance }\end{array}$ & & & $\begin{array}{l}-0.02 \\
(0.03)\end{array}$ & $\begin{array}{l}-0.02 \\
(0.03)\end{array}$ & & & & \\
\hline $\begin{array}{l}\text { Relocation over long } \\
\text { distance }\end{array}$ & & & $\begin{array}{l}-0.04 \\
(0.05)\end{array}$ & $\begin{array}{l}-0.06 \\
(0.05)\end{array}$ & & & & \\
\hline $\begin{array}{l}\text { Relocation over short } \\
\text { distance (lag) }\end{array}$ & & & & $\begin{array}{l}-0.01 \\
(0.02)\end{array}$ & & & & \\
\hline $\begin{array}{l}\text { Relocation over long } \\
\text { distance (lag) }\end{array}$ & & & & $\begin{array}{c}0.03 \\
(0.05)\end{array}$ & & & & \\
\hline Relocation for job & & & & & $\begin{array}{l}-0.05 \\
(0.05)\end{array}$ & $\begin{array}{l}-0.07 \\
(0.05)\end{array}$ & & \\
\hline Relocation for family & & & & & $\begin{array}{l}0.00 \\
(0.05)\end{array}$ & $\begin{array}{c}-0.02 \\
(0.05)\end{array}$ & & \\
\hline $\begin{array}{l}\text { Relocation for } \\
\text { housing/area }\end{array}$ & & & & & $\begin{array}{l}-0.01 \\
(0.03)\end{array}$ & $\begin{array}{l}-0.00 \\
(0.03)\end{array}$ & & \\
\hline $\begin{array}{l}\text { Relocation for other } \\
\text { motives }\end{array}$ & & & & & $\begin{array}{c}0.02 \\
(0.04)\end{array}$ & $\begin{array}{c}0.01 \\
(0.05)\end{array}$ & & \\
\hline Relocation for job (lag) & & & & & & $\begin{array}{c}0.04 \\
(0.04)\end{array}$ & & \\
\hline $\begin{array}{l}\text { Relocation for family } \\
\text { (lag) }\end{array}$ & & & & & & $\begin{array}{c}0.04 \\
(0.05)\end{array}$ & & \\
\hline $\begin{array}{l}\text { Relocation for } \\
\text { housing/area (lag) }\end{array}$ & & & & & & $\begin{array}{l}-0.02 \\
(0.02)\end{array}$ & & \\
\hline $\begin{array}{l}\text { Relocation for other } \\
\text { motives (lag) }\end{array}$ & & & & & & $\begin{array}{c}0.01 \\
(0.05)\end{array}$ & & \\
\hline $\begin{array}{l}\text { Relocation for the job of } \\
\text { both }\end{array}$ & & & & & & & $\begin{array}{l}-0.04 \\
(0.06)\end{array}$ & $\begin{array}{l}-0.08 \\
(0.06)\end{array}$ \\
\hline Relocation for his job & & & & & & & $\begin{array}{l}0.05 \\
(0.07)\end{array}$ & $\begin{array}{c}0.06 \\
(0.07)\end{array}$ \\
\hline Relocation for her job & & & & & & & $\begin{array}{l}0.21^{\text {** }} \\
(0.08)\end{array}$ & $\begin{array}{r}0.17^{*} \\
(0.08)\end{array}$ \\
\hline $\begin{array}{l}\text { Relocation for the job of } \\
\text { none }\end{array}$ & & & & & & & $\begin{array}{c}0.00 \\
(0.03)\end{array}$ & $\begin{array}{c}0.00 \\
(0.03)\end{array}$ \\
\hline $\begin{array}{l}\text { Relocation for the job of } \\
\text { both (lag) }\end{array}$ & & & & & & & & $\begin{array}{c}0.06 \\
(0.04)\end{array}$ \\
\hline $\begin{array}{l}\text { Relocation for his job } \\
\text { (lag) }\end{array}$ & & & & & & & & $\begin{array}{l}-0.03 \\
(0.07)\end{array}$ \\
\hline $\begin{array}{l}\text { Relocation for her job } \\
\text { (lag) }\end{array}$ & & & & & & & & $\begin{array}{c}0.08 \\
(0.09)\end{array}$ \\
\hline $\begin{array}{l}\text { Relocation for the job of } \\
\text { none (lag) }\end{array}$ & & & & & & & & $\begin{array}{l}-0.00 \\
(0.02)\end{array}$ \\
\hline Repeated relocations & $\begin{array}{l}-0.02 \\
(0.03) \\
\end{array}$ & $\begin{array}{l}-0.03 \\
(0.03) \\
\end{array}$ & $\begin{array}{c}-0.02 \\
(0.03) \\
\end{array}$ & $\begin{array}{l}-0.02 \\
(0.03) \\
\end{array}$ & $\begin{array}{l}-0.02 \\
(0.03) \\
\end{array}$ & $\begin{array}{l}-0.02 \\
(0.03) \\
\end{array}$ & $\begin{array}{l}-0.03 \\
(0.03) \\
\end{array}$ & $\begin{array}{l}-0.03 \\
(0.03) \\
\end{array}$ \\
\hline$\overline{\mathrm{LL}}$ & -10929.69 & -10929.54 & -10918.44 & -10917.94 & -10924.98 & -10923.09 & -10925.46 & -10923.74 \\
\hline N Observations & 18511 & 18511 & 18500 & 18500 & 18508 & 18508 & 18511 & 18511 \\
\hline $\mathrm{N}$ Individuals & 4922 & 4922 & 4922 & 4922 & 4922 & 4922 & 4922 & 4922 \\
\hline
\end{tabular}

Note: Outcome variable is egalitarian gender ideology (z-standardised), cluster robust standard errors in parentheses. Additional control variables in models as in Model 1 of Table $2 .+p<.1,{ }^{*} p<.05,{ }^{* *} p<.01$.

Data: BHPS (1991-2007, unweighted). 
Vidal \& Lersch: Changes in gender role attitudes following couples' residential relocations 